\title{
Defining 'Unhealthy': A Systematic Analysis of Alignment between the Australian Dietary Guidelines and the Health Star Rating System
}

\author{
Alexandra Jones 1,2,*(D), Karin Rådholm ${ }^{1,3}$ and Bruce Neal 1,2,4 \\ 1 The George Institute for Global Health, Sydney 2042, Australia; kradholm@georgeinstitute.org.au (K.R.); \\ bneal@georgeinstitute.org.au (B.N.) \\ 2 Charles Perkins Centre, University of Sydney, Sydney 2006, Australia \\ 3 Division of Community Medicine, Primary Care, Department of Medicine and Health Sciences, \\ Faculty of Health Sciences, Department of Local Care West, County Council of Östergötland, \\ Linköping University, 58183 Linköping, Sweden \\ 4 Department of Epidemiology and Biostatistics, School of Public Health, Faculty of Medicine, \\ Imperial College London, London SW7 2AZ, UK \\ * Correspondence: ajones@georgeinstitute.org.au; Tel.: +61-2-8052-4300
}

Received: 20 March 2018; Accepted: 13 April 2018; Published: 18 April 2018

\begin{abstract}
The Australian Dietary Guidelines (ADGs) and Health Star Rating (HSR) front-of-pack labelling system are two national interventions to promote healthier diets. Our aim was to assess the degree of alignment between the two policies. Methods: Nutrition information was extracted for 65,660 packaged foods available in The George Institute's Australian FoodSwitch database. Products were classified 'core' or 'discretionary' based on the ADGs, and a HSR generated irrespective of whether currently displayed on pack. Apparent outliers were identified as those products classified 'core' that received HSR $\leq 2.0$; and those classified 'discretionary' that received HSR $\geq 3.5$. Nutrient cut-offs were applied to determine whether apparent outliers were 'high in' salt, total sugar or saturated fat, and outlier status thereby attributed to a failure of the ADGs or HSR algorithm. Results: 47,116 products (23,460 core; 23,656 discretionary) were included. Median (Q1, Q3) HSRs were 4.0 (3.0 to 4.5) for core and 2.0 (1.0 to 3.0) for discretionary products. Overall alignment was good: $86.6 \%$ of products received a HSR aligned with their ADG classification. Among 6324 products identified as apparent outliers, $5246(83.0 \%)$ were ultimately determined to be ADG failures, largely caused by challenges in defining foods as 'core' or 'discretionary'. In total, $1078(17.0 \%)$ were determined to be true failures of the HSR algorithm. Conclusion: The scope of genuine misalignment between the ADGs and HSR algorithm is very small. We provide evidence-informed recommendations for strengthening both policies to more effectively guide Australians towards healthier choices.
\end{abstract}

Keywords: nutrient profiling; front-of-pack labelling; dietary guidelines; nutrition policy; health star rating

\section{Introduction}

Unhealthy diets—high in salt, harmful fats, added sugar and energy—are a leading cause of death and disability in Australia [1]. Australia has some of the highest obesity rates in the world: nearly two-thirds of Australian adults and one in four children are now overweight or obese. Unprecedented availability and aggressive marketing of processed and pre-packaged foods and beverages are a key driver of obesity and diet-related conditions including high blood pressure, heart disease, stroke, 
type 2 diabetes, some forms of cancer, dementia and dental caries [2]. Obesity alone is estimated to cost Australia more than $\$ 8.6$ billion annually [3].

The World Health Organization recommends a comprehensive suite of population health approaches to promote healthier diets. These include laws and regulations, tax and price interventions, community-based measures in facilities such as schools and hospitals, and public education through social marketing campaigns [4]. Despite the increasing impact of poor diet on Australia's health, few of these preventive strategies have been taken up at a federal level.

Two policy areas where Australia has been benchmarked as performing well against international best-practice are in adoption of food-based dietary guidelines and front-of-pack nutrition labels [5]. The current Australian Dietary Guidelines (ADGs) were introduced in 2013 to promote health and wellbeing while reducing the risk of chronic disease [6]. In 2014, Australia adopted the Health Star Rating System (HSR), an interpretive nutrition labelling scheme that rates foods from 0.5 to 5.0 stars on the front-of-pack [7]. An example of the HSR graphic and the Australian Guide to Healthy Eating, which provides a practical visual representation the food groups recommended by the ADGs and their proportions, are included at Appendix A.

While inherently related in their intent to guide Australians towards healthier choices, the two measures differ in aspects of their purpose and design (Table 1). For example, the ADGs provide information on dietary patterns, amounts and food groups that support health through detailed guidance documents that are for use by health professionals, policy makers, educators, food manufacturers and researchers [6]. By contrast, HSR uses an algorithm to quantify selected aspects of individual foods, generating a summary score displayed in a simple symbol intended to both target consumers at the point-of-sale, and offer incentives for manufacturers to improve recipes to receive a higher rating $[8,9]$. The relative strengths of each measure suggest potential opportunities for the ADGs and HSR to operate synergistically for maximum public health impact. At the same time, tension between the two approaches is apparent in academic and media critique of HSR, particularly where high profile products have been highlighted for displaying labels allegedly inconsistent with ADG recommendations [10,11].

With a five year review of the HSR system currently underway, our objective was to assess one of the review's key elements, namely the degree of alignment between the two policies and specifically in their mechanism for defining food as healthy or unhealthy. Policy coherence is important not only because of the need to provide consistent dietary messaging to Australians, but also because inappropriate HSR scores or ADG recommendations threaten the credibility and sustainability of both policies. By identifying areas and causes of misalignment, our aim was to make evidence-informed recommendations for refining both policies, thereby strengthening Australia's efforts to promote healthier diets. 
Table 1. Key features of Australian Dietary Guidelines and the Health Star Rating System.

\begin{tabular}{|c|c|c|c|c|c|c|}
\hline & Objective & Mechanism & Target Audience & Classification of Foods & Developed by & Governed by \\
\hline $\begin{array}{l}\text { Australian Dietary } \\
\text { Guidelines }\end{array}$ & $\begin{array}{l}\text { Provide information } \\
\text { on food groups, } \\
\text { amounts and dietary } \\
\text { patterns that support } \\
\text { health. }\end{array}$ & $\begin{array}{l}\text { Guideline Documents, } \\
\text { Summary and } \\
\text { Educator Guide. } \\
\text { Australian Guide to } \\
\text { Healthy Eating } \\
\text { graphic }\end{array}$ & $\begin{array}{l}\text { Health professionals, } \\
\text { policy makers, } \\
\text { educators, food } \\
\text { manufacturers, food } \\
\text { retailers and } \\
\text { researchers. }\end{array}$ & $\begin{array}{l}\text { Classification of foods into Five } \\
\text { Food Groups that form the basis of } \\
\text { a healthy diet, and 'discretionary' } \\
\text { foods defined by the presence of } \\
\text { saturated fat, added sugars, salt } \\
\text { and/or alcohol, whose intake is to } \\
\text { be limited. }\end{array}$ & $\begin{array}{l}\text { National Health and } \\
\text { Medical Research } \\
\text { Council (NHMRC) } \\
\text { via standardised } \\
\text { guideline process. } \\
\text { Working Committee } \\
\text { incl. public health } \\
\text { and industry } \\
\text { representation. }\end{array}$ & $\begin{array}{l}\text { NHMRC } \\
\text { NHMRC considers } \\
\text { whether to update after } \\
5 \text { years. } \\
\text { Maximum interval prior } \\
\text { to update is } 10 \text { years. }\end{array}$ \\
\hline Health Star Rating & $\begin{array}{l}\text { Simplify nutrition } \\
\text { information available } \\
\text { on back-of-pack to } \\
\text { differentiate between } \\
\text { individual foods } \\
\text { more likely to be part } \\
\text { of a healthy diet from } \\
\text { those that are less } \\
\text { healthy. }\end{array}$ & $\begin{array}{l}\text { Front-of-pack label to } \\
\text { be applied voluntarily } \\
\text { by food retailers and } \\
\text { manufacturers using } \\
\text { relevant policy } \\
\text { documents. }\end{array}$ & $\begin{array}{l}\text { Consumers at point of } \\
\text { purchase. } \\
\text { Food retailers and } \\
\text { manufacturers. }\end{array}$ & $\begin{array}{l}\text { A nutrient profile model is used to } \\
\text { score individual products from } \\
0.5 \text { to } 5.0 \text { stars. The algorithm } \\
\text { considers energy, negative nutrients } \\
\text { the ADGs recommend eating less of } \\
\text { (saturated fat, sugars and sodium), } \\
\text { and foods the ADGs recommend } \\
\text { eating more of (fruits, vegetables, } \\
\text { nuts and legumes) as well as in } \\
\text { some instances, allowing points for } \\
\text { protein and dietary fibre content. }\end{array}$ & $\begin{array}{l}\text { Australian Fed., State } \\
\text { and territory } \\
\text { governments in } \\
\text { partnership with food } \\
\text { industry, consumer } \\
\text { and public health } \\
\text { groups. }\end{array}$ & $\begin{array}{l}\text { Health Star Rating } \\
\text { Advisory Committee. } \\
\text { Representation from } \\
\text { Australian Federal, State } \\
\text { and Territory } \\
\text { governments as well as } \\
\text { food industry, consumer } \\
\text { and public health groups. } \\
2 \text { year monitoring report } \\
\text { and } 5 \text { year review process } \\
\text { set down at adoption. }\end{array}$ \\
\hline
\end{tabular}




\section{Methods}

This was a cross-sectional examination of packaged foods and beverages (hereafter referred to as foods) available in Australia.

\subsection{Data Source}

We analysed items included in The George Institute for Global Health's Australian FoodSwitch Database [12]. The database contains nutrition label information from packaged foods systematically collected by The George Institute through large-scale annual surveys, as well as provided directly by manufacturers and consumers on a rolling basis. In total, this data represents more than $90 \%$ of products available in the Australian market. For this study, we used information extracted directly from the back-of-pack nutrition information panel. Energy (kJ/100 g), protein (g/100 g), saturated fat (g/100 g), total sugar $(\mathrm{g} / 100 \mathrm{~g})$, and sodium $(\mathrm{mg} / 100 \mathrm{~g})$ are mandatory on the Australian nutrient declaration but details on fruit, vegetable, nut and legume (FVNL) (\%), concentrated FVNL (\%), and fibre (g/100 g) are optional. Where such details were absent, appropriate levels were estimated using information drawn from the back-of-pack ingredients list, generic food composition databases, or by analogy with similar products using methods described previously [12]. The estimation process provides a proxy value for each nutritional indicator at the finest category level for more than 1000 individual food subcategories. Proxy values are then substituted for each product in that category for which data are missing.

\subsection{Product Classification}

Classification of products was based on the system developed by the Global Food Monitoring Group and incorporated into FoodSwitch [13]. This hierarchical system is designed to monitor the nutrient composition of processed foods around the world. It classifies foods into major categories (e.g., bread and bakery products), categories (e.g., bread), and subcategories (e.g., pita bread). Our analysis included only packaged food items. We excluded infant foods and formula, vitamins and supplements, formulated supplementary sports foods, foods for special medical purposes and alcoholic beverages because these foods have been specifically deemed outside the scope of HSR [14]. This left 15 major categories for analysis. Within these, we also excluded subcategories of plain tea and coffee, herbs and spices, baking powders, yeasts and gelatines, as these foods do not contribute significantly to nutrient intake, are not required to display a nutrition information panel [15], and are also therefore not required to display a HSR.

\subsection{Calculation of the Health Star Rating}

The HSR was calculated in alignment with the methods described in the 'Guide for industry to the Health Star Rating Calculator' for all products sold, regardless of whether a HSR was reported on the pack [16]. In short, foods were categorised into one of six HSR categories (i.e., non-dairy beverages; dairy beverages; oils and spreads; cheese and processed cheese; all other dairy foods; all other non-dairy foods). Baseline points were calculated based on the energy, saturated fat, total sugar, and sodium content per $100 \mathrm{~g}$. Modifying points for FVNL\%, concentrated FVNL\%, protein, and fibre were calculated, where applicable. A HSR 'score' was calculated by subtracting the modifying points from baseline points. This score is then converted to a HSR based upon a defined scoring matrix for each of the six categories [16]. The HSR ranges from 0.5 to 5.0 stars in ten half-star increments. A higher HSR reflects a healthier product.

\subsection{Classification of Foods under the Australian Dietary Guidelines}

We classified foods as 'core' or 'discretionary' according to ADG guidance. In short, core foods were defined as those from the ADGs Five Food Groups: grain (cereal) foods, mostly wholegrain and/or high cereal fibre varieties; vegetables and legumes/beans; fruit; milk, yoghurt, cheese and/or 
alternatives, mostly reduced fat; and lean meats and poultry, fish, eggs, tofu, nuts and seeds and legumes/beans. Together, these core foods form the basis of a healthy diet. Discretionary foods are those not necessary to provide nutrients the body needs, and are defined for ADG purposes as those 'high in' saturated fats, added sugars, and/or salt or alcohol [6]. As the ADG documents themselves provide only limited examples of discretionary choices and no objective measure of 'high in', we relied upon the Australian Bureau of Statistics (ABS) 'Discretionary Food List' [17] as the best-available reference for classifying each product for the purposes of this analysis. The main principle used by the ABS to classify foods as discretionary is that they were specified or inferred in the ADGs and supporting documents as discretionary [17]. ABS classifications determined at a detailed food category level were matched to FoodSwitch categories to classify each category as 'core' or 'discretionary'.

In some categories, such as those involving mixed foods, the ABS applies additional nutrient criteria to define core and discretionary. The nutrient cut-offs specified are those used in the modelling that supported the original ADG development [18]. Where provided, e.g., pizza with saturated fat content $\leq 5 \mathrm{~g} / 100 \mathrm{~g}$ is 'core' while pizza with saturated fat content $>5 \mathrm{~g} / 100 \mathrm{~g}$ is 'discretionary', these were also applied.

\subsection{Statistical Analysis}

Cross-tabulations of ADG status and HSR were prepared for the twenty cells comprising core, discretionary and the ten possible HSR values $(0.5,1.0,1.5,2.0,2.5,3.0,3.5,4.0,4.5$ or 5.0). In the absence of endorsed HSR cut-offs for healthy or unhealthy, we identified products as 'apparent outliers' when the product was categorised 'core' by the ADGs but received a HSR $\leq 2.0$, suggesting an unhealthy nutritional profile, or the product was categorised as 'discretionary' by the ADG but received a HSR $\geq 3.5$, suggesting a healthy nutritional profile. The number and proportion of products deemed apparent outliers was determined overall, for each of the 15 major food categories included and by category and sub-category where helpful.

To further understand the reasons for outlier status of products, and in particular the potential impact of the undefined 'high in' terminology used by the ADGs, we applied additional nutrient cut-off criteria. In the absence of any existing international standard or guidance, we drew from the United Kingdom (UK) multiple traffic-light nutrient profile model, which was validated during development in the UK context, and has been subsequently used to model dietary outcomes elsewhere [19-21]. Specifically, the cut points used to apply red traffic lights for salt, total sugar and saturated fat were used to provide a quantitative measure of the ADGs 'high in' terminology. These were applied to apparent outliers, and products were removed or retained on the basis of qualifying for none, one or multiple red traffic lights:

- Apparent outliers that scored a low HSR but were assigned 'core' status by the ADGs were not considered 'genuine outliers' if they were sufficiently 'high in' salt, saturated fat and/or sugar to warrant at least one red traffic light.

- Apparent outliers that scored a high HSR but were assigned 'discretionary' status by the ADGs were not considered 'genuine outliers' if nutrient values for salt, saturated fat and/or sugar were not sufficiently high to warrant at least one red traffic light.

Apparent outliers that were deemed not to be genuine outliers after application of these 'high in' cut points were deemed 'ADG failures'. All others were deemed 'HSR failures'. Reasons for failures and potential solutions were systematically recorded (Appendix B).

\section{Results}

In total, 65,660 packaged products available in Australian supermarkets between 1 January 2013 and 30 June 2017 were identified in the FoodSwitch database. Of these, 11,431 had insufficient product information to enable categorization and generate a HSR, and a further 7113 were in categories excluded from HSR. 
This left 47,116 products for analysis. Of these, only 3524 (7.5\%) were displaying HSR on pack at the date of data extraction (30 June 2017).

\subsection{HSR Distribution by Core and Discretionary}

There were 23,460 (49.8\%) core products and 23,656 (50.2\%) discretionary products. Distribution of HSR by core and discretionary is shown in Figure 1.

In total, the median (IQR) of calculated HSR scores was 3 (1.5 to 4). Core products had a median (IQR) calculated HSR score of 4.0 (3.0 to 4.5) and discretionary products had a median (IQR) calculated HSR score of 2.0 (1.0 to 3.0).

Of products displaying HSR on pack, the overall median (IQR) value was 4.0 (3.0 to 4.5); out of these, $2131(60.5 \%)$ were core products and 1393 (39.5\%) were discretionary.

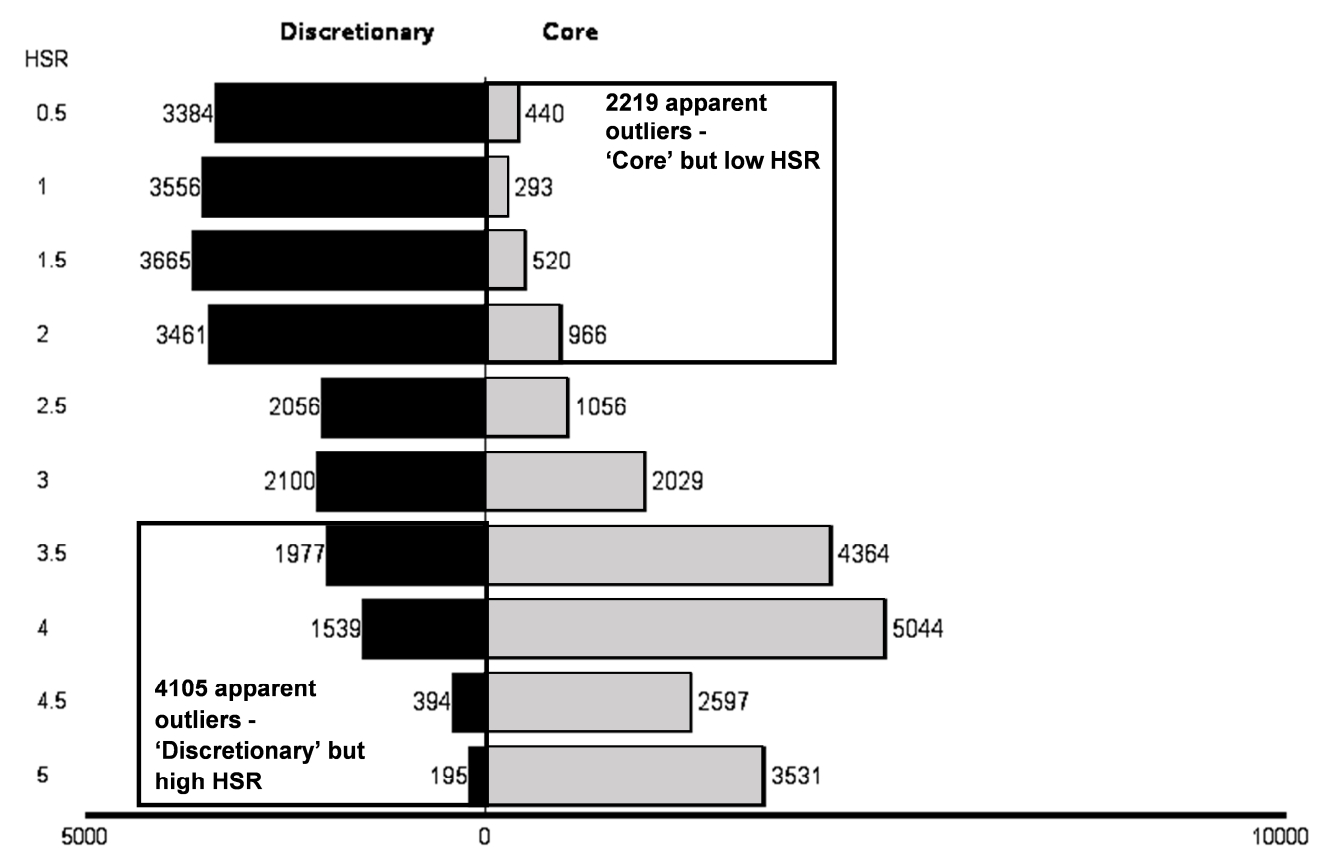

Figure 1. Distribution of HSR by core and discretionary with apparent outliers.

\subsection{Apparent Outliers}

There were $6324(13.4 \%)$ apparent outliers. In total, 2219 were apparent core outliers, representing $9.5 \%$ of all core products and $4.7 \%$ of the total sample. In total, 4105 apparent discretionary outliers were identified, representing $17.4 \%$ of all discretionary products and $8.7 \%$ of the total sample (Figure 1 and Table 2).

As seen in Figure 2, the distribution of products and number of apparent outliers varied greatly across the 15 major food categories and by core and discretionary classification. The major categories with the largest proportion of apparent outliers were sauces, dressings, spreads and dips $(19.9 \%)$; dairy $(18.4 \%)$; and snack foods $(10.3 \%)$.

Table 2. Cross tabulation of apparent outliers, and attribution of reason for outlier status (i.e., ADG failure or HSR failure) after application of traffic light cut-offs.

\begin{tabular}{cccc}
\hline & Apparent Outliers & ADG Failure & HSR Failure \\
\hline HSR $\leq 2.0$ & 2219 & 2116 & 103 \\
HSR $\geq 3.5$ & 4105 & 3130 & 795 \\
\hline
\end{tabular}


Proportion of apparent core outliers (assigned 'core' but low HSR)

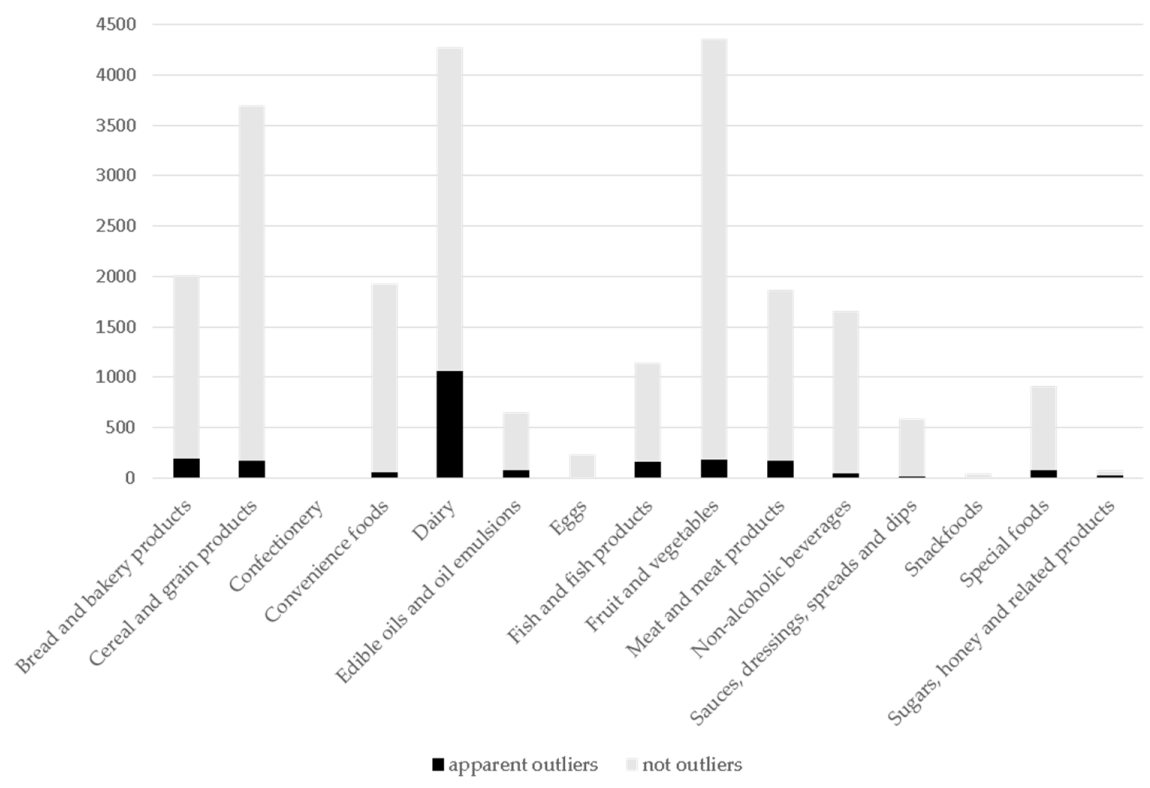

Proportion of apparent discretionary outliers (assigned 'discretionary' but high HSR)

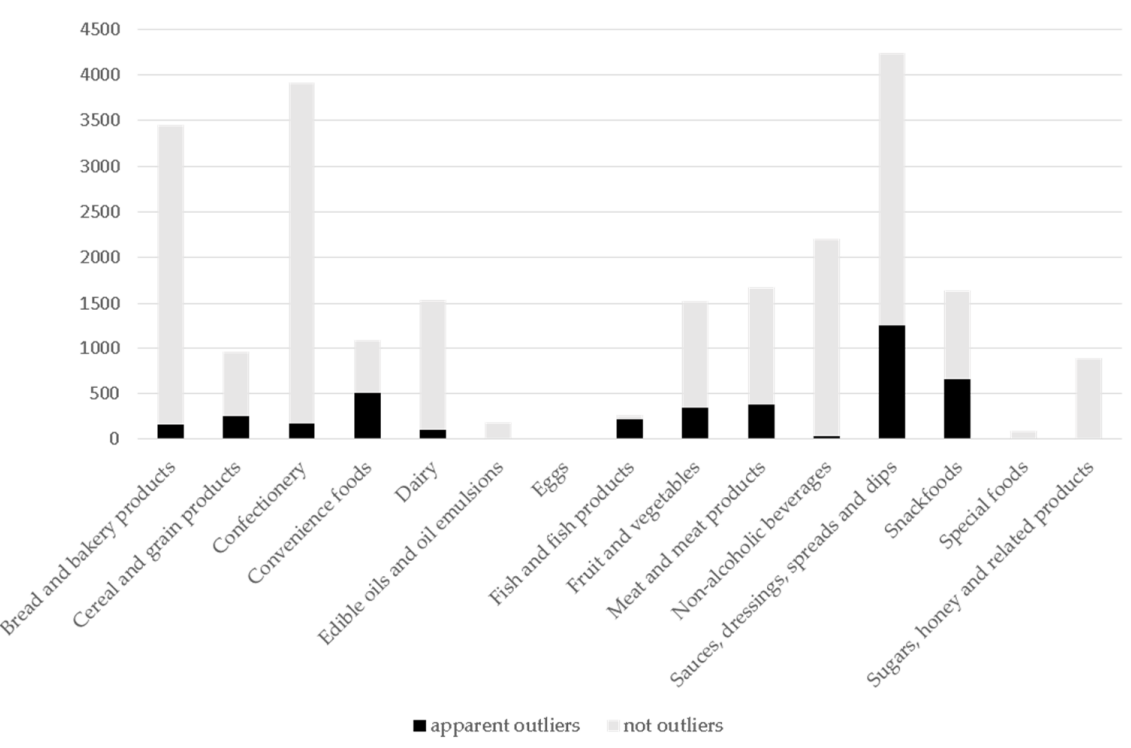

Figure 2. Apparent core and discretionary outliers-numbers of products and numbers of outliers by major food category.

\subsection{Application of Traffic Light Cut-Offs}

Application of cut-points to identify foods 'high in' salt, total sugar and saturated fat greatly reduced the number of outliers (Table 2).

Among the apparent core outliers, 2116/2219 (95.4\%) had at least one red traffic light, signifying high levels of salt (1159), saturated fat (1136), and/or sugar (538). These foods were deemed ADG failures on the basis that high levels of these negative nutrients form the basis of the ADG definition of discretionary foods. This left 103 (4.6\%) core food outliers that received a low HSR despite not being 'high in' any negative nutrients. These results were genuinely misaligned with the ADGs and deemed HSR failures. Figure 3 and Table 3 detail these results by major food category. The three categories with HSR failures were fruit and flavoured yoghurts; and flavoured teas. The yoghurts had amber 
lights for saturated fat and sugar, and the flavoured teas had amber lights for sugar. Both categories likely had a mix of naturally occurring and added sugar.

In the discretionary outlier group, 3130/4105 (76.2\%) of apparent outliers had no red traffic lights, signifying they were not 'high in' salt, sugar or saturated fat and were therefore deemed ADG failures. This left 975 (23.8\%) apparent discretionary outliers receiving a high HSR despite being 'high in' salt (510), sugar (296) and/or saturated fat (235). These foods were deemed HSR failures. Figure 3 and Table 4 outline these findings by major food category. The largest number of HSR failures occurred in sauces, dressings, spreads and dips; savoury snacks; meat and meat products; and, convenience foods. Products in these categories predominantly had red traffic lights for salt and to a lesser degree, saturated fat despite receiving HSR $\geq 3.5$.

Taking core and discretionary together, 5246 outliers (83\%) were attributable to ADG failure. This left 1078 outliers $(17 \%)$ attributable to a failure of the algorithm.

A detailed list of core and discretionary outliers is included at Appendix B.
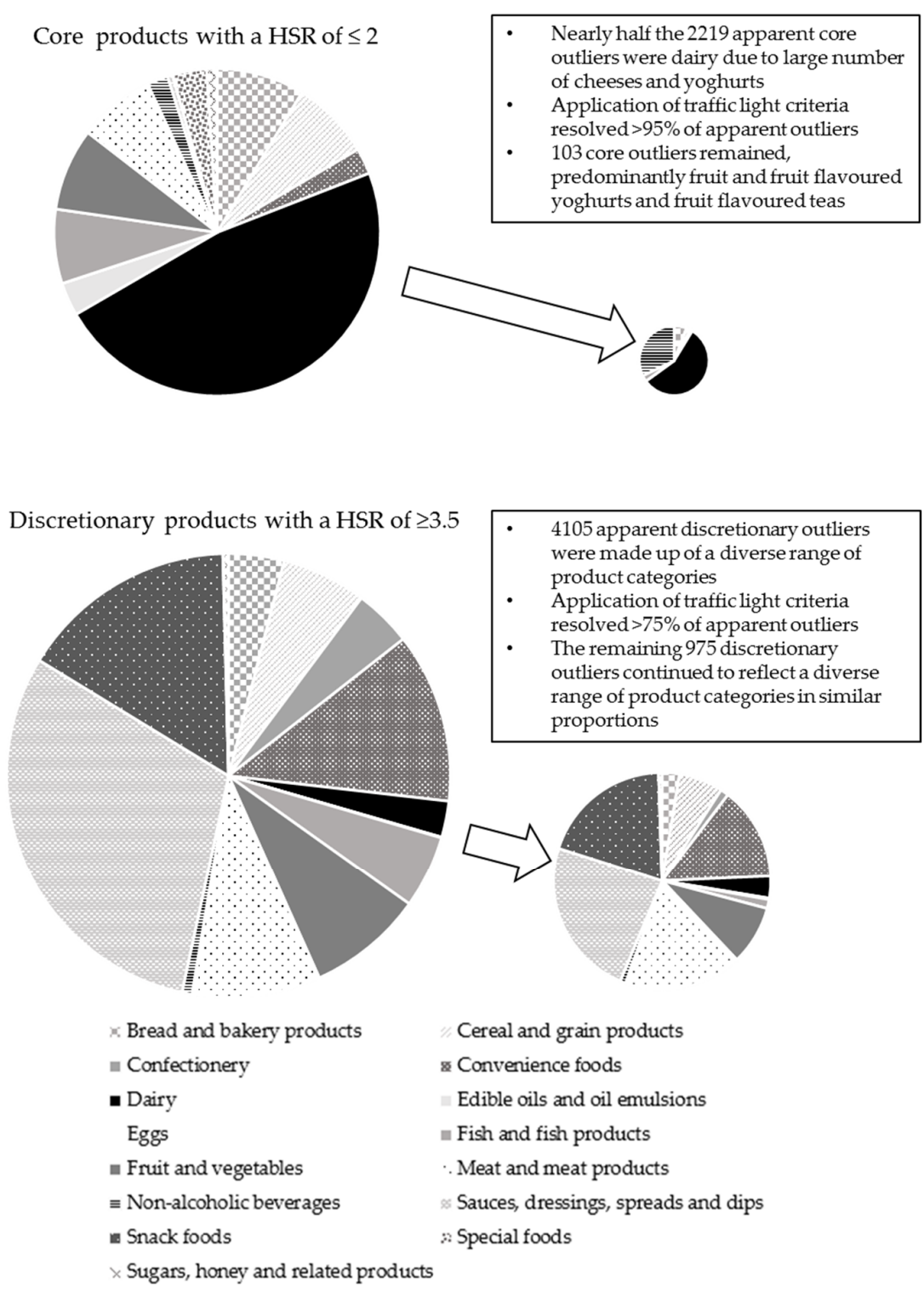

Figure 3. Apparent and genuine outliers by major food category (areas of circles are proportional to numbers of products). 
Table 3. Core products with HSR $\leq 2.0$.

\begin{tabular}{|c|c|c|c|c|c|}
\hline Major Food Category & $\begin{array}{l}\text { Number of } \\
\text { Apparent Outliers }\end{array}$ & $\begin{array}{l}\text { Number of Products } \\
\text { with Any Red TLL }\end{array}$ & $\begin{array}{l}\text { Outliers } \\
\text { Remaining }\end{array}$ & $\begin{array}{l}\text { Illustrative Examples of } \\
\text { Outliers Remaining }\end{array}$ & Characteristics of Remaining Outliers \\
\hline 1 Bread and bakery products & 193 & 187 & 6 & Pancake mixes, tortillas & $\begin{array}{l}\text { - All have amber traffic lights for saturated fat and salt, and some also } \\
\text { for sugar }\end{array}$ \\
\hline 2 Cereal and grain products & 174 & 172 & 2 & Rice puff cereal, noodles & $\begin{array}{l}\text { - } \quad \text { Breakfast cereal has amber lights for salt and sugar } \\
\text { - } \quad \text { Noodles have amber lights for saturated fat and salt }\end{array}$ \\
\hline 3 Confectionery & 0 & - & - & & - \\
\hline 4 Convenience foods & 57 & 56 & 1 & Antipasto product & - Has amber traffic lights for salt, saturated fat and sugar \\
\hline 5 Dairy & 1056 & 997 & 58 & $\begin{array}{l}\text { Fruit and flavoured } \\
\text { yoghurts, natural yoghurt }\end{array}$ & $\begin{array}{l}\text { - All are in yoghurt category. More than } 90 \% \text { are yoghurts with fruit or } \\
\text { flavourings that have amber traffic lights for saturated fat and sugar } \\
\text { Two products are natural yoghurts with amber traffic lights for } \\
\text { saturated fat and salt }\end{array}$ \\
\hline 6 Edible oils and oil emulsions & 73 & 73 & 0 & & - \\
\hline 7 Eggs & 0 & - & - & & - \\
\hline 8 Fish and fish products & 163 & 160 & 3 & $\begin{array}{l}\text { Salmon pate, garlic } \\
\text { prawns }\end{array}$ & $\begin{array}{l}\text { - All have amber lights for salt and at least one other of sugar and } \\
\text { saturated fat }\end{array}$ \\
\hline 9 Fruit and vegetables & 181 & 181 & 0 & & - \\
\hline 10 Meat and meat products & 168 & 168 & 0 & & - \\
\hline 11 Non-alcoholic beverages & 46 & 13 & 33 & $\begin{array}{l}\text { Fruit flavoured teas and } \\
\text { iced teas, matcha }\end{array}$ & $\begin{array}{l}\text { - Some teas, unlike most, carried a nutrient information panel and } \\
\text { therefore had a HSR generated despite being low in nutrients overall } \\
\text { - Iced teas with added sugar are discretionary but these teas contained } \\
\text { fruit and in the absence of added sugar labelling it was not possible to } \\
\text { definitively categorise these drinks as core or discretionary } \\
\text { - Growth in popularity of new beverages categories (e.g., matcha, chai) } \\
\text { suggest more classification guidance needed }\end{array}$ \\
\hline 12 Sauces, dressings, spreads and dips & 11 & 11 & 0 & & - \\
\hline 13 Snack foods & 0 & - & - & & - \\
\hline 14 Special foods & 75 & 75 & 0 & & - \\
\hline 15 Sugars, honey and related products & 23 & 23 & 0 & & - \\
\hline All & 2219 & 2116 & 103 & & \\
\hline
\end{tabular}

TLL = Traffic Light Label, referring to the threshold set for a red traffic light under the UK nutrient profiling model. 
Table 4. Discretionary products with HSR $\geq 3.5$.

\begin{tabular}{|c|c|c|c|c|c|}
\hline Major Food Category & $\begin{array}{l}\text { Number of } \\
\text { Apparent Outliers }\end{array}$ & $\begin{array}{l}\text { Number of Products } \\
\text { No Red TLL }\end{array}$ & $\begin{array}{l}\text { Outliers } \\
\text { Remaining }\end{array}$ & $\begin{array}{l}\text { Illustrative Examples of Outliers } \\
\text { Remaining }\end{array}$ & Characteristics of Remaining Outliers \\
\hline 1 Bread and bakery products & 166 & 141 & 25 & $\begin{array}{l}\text { Sweet biscuits, savoury breads and } \\
\text { pastries }\end{array}$ & $\begin{array}{l}\text { - Products have red TLL for sugar (sweet breads and } \\
\text { biscuits), salt (savoury breads and biscuits) or saturated } \\
\text { fat (puff pastries, quiche) }\end{array}$ \\
\hline 2 Cereal and grain products & 254 & 190 & 64 & $\begin{array}{l}\text { Breakfast cereals, cereal and } \\
\text { nut-based bars }\end{array}$ & $\begin{array}{l}\text { - Most have red TLL for sugar and a few salt or } \\
\text { saturated fat }\end{array}$ \\
\hline 3 Confectionery & 173 & 161 & 12 & $\begin{array}{l}\text { Jellies, cocoa powder, chocolate } \\
\text { strawberries }\end{array}$ & $\begin{array}{l}\text { - Products have red TLL for sugar (jellies) or saturated fat } \\
\text { (chocolate based items) }\end{array}$ \\
\hline 4 Convenience foods & 508 & 372 & 136 & Ready meals, meal kits & $\begin{array}{l}\text { - } \quad \text { Most products have red TLL for saturated fat and/or salt } \\
\text { - A smaller number have red TLL for sugar }\end{array}$ \\
\hline 5 Dairy & 108 & 76 & 32 & Rice puddings & - All products have red TLL for sugar \\
\hline 6 Edible oils and oil emulsions & 2 & 0 & 2 & Almond oil, lemon butter & - All products have red TLL for saturated fat or sugar. \\
\hline 7 Eggs & 0 & - & - & & - \\
\hline 8 Fish and fish products & 219 & 206 & 13 & Salt and pepper products, fish cakes & - $\quad$ All products have red TLL for salt. \\
\hline 9 Fruit and vegetables & 347 & 261 & 86 & $\begin{array}{l}\text { Fruit bars and bites, pickled } \\
\text { vegetables }\end{array}$ & $\begin{array}{l}\text { - Fruit products have red TLL for sugar (fruit bars, bites) } \\
\text { and sometimes saturated fat (fruit bites with coconut) } \\
\text { Vegetable products have red TLL for salt (pickled } \\
\text { vegetables, olives) }\end{array}$ \\
\hline 10 Meat and meat products & 384 & 213 & 171 & $\begin{array}{l}\text { Sliced meats, frozen and chilled } \\
\text { meats }\end{array}$ & $\begin{array}{l}\text { - Most products have red TLL for salt or saturated fat and a } \\
\text { few for both }\end{array}$ \\
\hline 11 Non-alcoholic beverages & 30 & 22 & 8 & Milk flavourings, beverages mixes & $\begin{array}{l}\text { Products have red TLL for sugar. Are able to take } \\
\text { advantage of 'as prepared' rules }\end{array}$ \\
\hline 12 Sauces, dressings, spreads and dips & 1245 & 1015 & 230 & Salty dips, relishes and chutneys & $\begin{array}{l}\text { - Most products have red TLL for salt, some for sugar and a } \\
\text { few for saturated fat }\end{array}$ \\
\hline 13 Snack foods & 652 & 461 & 191 & $\begin{array}{l}\text { Potato chips, vegetable and } \\
\text { legume-based snacks, corn chips }\end{array}$ & $\begin{array}{l}\text { - Most products have red TLL for salt, some for saturated } \\
\text { fat, a few for sugar and a few for several }\end{array}$ \\
\hline 14 Special foods & 2 & 2 & - & & - \\
\hline 15 Sugars, honey and related products & 15 & 10 & 5 & Syrups & - Products all have red TLL for sugar \\
\hline All & 4105 & 3130 & 975 & & \\
\hline
\end{tabular}

TLL $=$ Traffic Light Label, referring to the threshold set for a red traffic light under the UK nutrient profiling model. 


\section{Discussion}

In contrast to intense media attention on occasional anomalies, this large quantitative analysis suggests that the scope of genuine misalignment between the ADGs and the HSR algorithm across the Australian food supply is very small.

The degree of policy coherence demonstrated by our results is encouraging, though perhaps not surprising given the well-recognised relationship between nutrients, foods and dietary patterns [22]. Our results are consistent with existing research demonstrating that the HSR algorithm is aligned well overall with the ADGs [23-25], and that the median HSR of core foods is significantly higher than that of discretionary foods $[10,23,26]$.

While these results are promising, it is reasonable to seek better alignment between the HSR and the ADGs if this increases their public health impact. The results of this work suggest directions for improvement.

Specific recommendations for improving alignment are set out in Table 5.

Table 5. Priority recommendations for reviewing the HSR algorithm and ADG definitions to improve alignment.

- $\quad$ Review the weighting given to salt in HSR algorithm, given the large number of sauces, dips, savoury snacks, sliced meats and convenience foods that receive a high HSR despite being high in salt. This would be supported by the 2017 update of Australia's Nutrient Reference Value for sodium.

- $\quad$ Review the eligibility of fried or pickled vegetables and dried fruits for FVNL points given their receipt of high HSR scores despite being high in negative nutrients. This would be supported by references in ADG text (but not the ABS Table) that such products should be only consumed occasionally and in small amounts.

- Review the weighting given to sugar, and/or incorporate added sugars given the large number of outliers in categories likely to contain a mix of naturally occurring and added sugars. These appeared at both ends, i.e., core yoghurts with fruit or flavours, fruit flavoured teas, as well as discretionary chutneys, breakfast cereals, muesli and fruit bars, dairy desserts and table sauces.

- Review the ADG definition of discretionary, including additional guidance on 'high in' criteria for saturated fat, added sugars and salt to elucidate, for example, at what point a flavoured yoghurt can more properly be considered a dairy dessert.

- $\quad$ Review a wide range of ABS table classifications (see Appendix B) including: 'core' status of breakfast cereals with sugar up to $30 \mathrm{~g} / 100 \mathrm{~g}$, cheese regardless of salt and saturated fat content, yoghurt and flavoured milks regardless of sugar or saturated fat content, most meat and fish regardless of salt content; 'discretionary' status of vegetable and legume based dips, 'potato products' and crumbed fish intended for home baking; and, appropriate treatment of growing product categories such as breakfast beverages and coconut products.

- $\quad$ Once the algorithm is reviewed, make HSR mandatory to enable consumers to receive the full benefit of the system's performance across the food supply.

While there is considerable current focus on review of the HSR algorithm, these results highlight a parallel urgent need for review of the ADG text and corresponding ABS Table (See Appendix B).

Our findings can be differentiated from a recent analysis of foods carrying HSR labels on pack during voluntary implementation [19]. That analysis of 1269 new products found that 57\% were core items and 43\% discretionary. The authors concluded that HSR labelling was undermining ADG recommendations by facilitating the marketing of discretionary foods because more than half of those defined as discretionary displayed a HSR $\geq 2.5$. Our work suggests caution in this interpretation given the small sample size of the prior study, identified failings of the ADGs in regard to the classification of some foods, and the highly selective subset of products studied. The conclusions may also reflect 
the simplistic approach ultimately taken by the ADGs, in seeking to dichotomise foods as core or discretionary, when healthiness of products is almost certainly distributed along a continuum.

The present analysis benefits from the large number of foods included, their robust representation of the broader Australian food supply and the comprehensive and systematic approach taken to the evaluation and presentation of the data. Our decision to use the UK traffic light criteria as a quantitative measure of 'high in' was an objective approach to quantifying the textual guidance provided by the ADGs. The international food standards agency, the Codex Alimentarius Committee, recently agreed to commence work to develop 'high in' criteria for salt, sugar and saturated fat given increasing international interest in this area. This process is likely to take several years [27].

Some limitations also need to be mentioned. FVNL content and fibre are not currently mandatory on back-of-pack nutrition information panels in Australia and missing values were therefore estimated from ingredients lists, food composition databases, and other sources. This analysis does not capture related concerns raised by stakeholders to the Government's five year review [28] regarding the high HSRs received by fruit juices, breakfast cereals with a sugar content $\leq 30 \mathrm{~g} / 100 \mathrm{~g}$, and breakfast beverages. These issues likely represent HSR failures but are not identified as 'outliers' in this analysis because the ADG text and/or ABS Table also identify these products (arguably incorrectly) as core.

Our ability to measure alignment was limited by the components of foods considered by the HSR algorithm. For example, HSR currently relies on total sugar but the ADGs recommend to limit added sugars specifically. Areas where we believe this distinction may have impacted outlier status include flavoured yoghurts and milks, breakfast cereals, muesli bars, chutneys and table sauces as noted in detail in Appendix B. Previous work has indicated that incorporating added sugar into the HSR algorithm would improve its ability to discriminate between core and discretionary [26,29]. This would be best facilitated by updating mandatory nutrient information panel (NIP) requirements to include transparent information on added sugars. Alternatively, added sugar values could be systematically estimated using available information from current NIPs in combination with the ingredients list, using published methods [30]. A similar approach is currently provided to companies claiming points for fruit, vegetable, nut and legume content that is also not required in the NIP.

Our analysis was also limited in scope to packaged products only. While half our sample were classified core (suggesting that not all packaged foods are unhealthy), some foods recommended by the ADGs (i.e., whole fresh fruit and vegetables) are generally sold without packaging. Current consideration of whether to extend HSR to these products (e.g., through shelf talkers) could further enhance alignment between the HSR and ADGs [31].

\section{Conclusions}

This work illustrates the complexity of defining foods as 'healthy' or 'unhealthy' across the huge range of packaged products available in the current Australian food supply.

Like other front-of-pack labelling systems that rely on an underlying profiling model, the HSR algorithm is intended as a tool to quantify selected aspects of individual foods rather than to be a complete source of dietary advice. Nevertheless, our results are consistent with WHO recognition that such tools are a helpful method to use in conjunction with interventions aimed at improving the overall nutritional quality of diets [32].

Rather than undue focus on perfect alignment or determination of the superiority of the HSR or ADGs, a more nuanced understanding of the relative contribution (and inherent limitations) of each suggests areas where the design and implementation of both policies could be strengthened to guide Australian consumers towards healthier choices.

Acknowledgments: A.J. is supported by an Australian Government Research Training Program (RTP) Scholarship. B.N. is supported by a National Health and Medical Research Council of Australia Principal Research Fellowship (APP1106947) and holds and NHMRC Program Grant (APP1052555) and Centre for Research excellence funding (APP1117300). K.R. is funded by a County Council of Östergötland international fellowship. 
Author Contributions: A.J., K.R. and B.N. conceived and designed the research; A.J. and K.R. conducted the analysis (though K.R. conducted the statistical analysis specifically); A.J. wrote the first draft of the paper. K.R. and B.N. reviewed the manuscript and contributed to subsequent drafts.

Conflicts of Interest: Alexandra Jones is a member of the Technical Advisory Group (TAG) to the Australasian Health Star Rating Advisory Committee (HSRAC). Neither the TAG nor the HSRAC had any role in the study design, data collection, decision to publish, or preparation of the manuscript.

\section{Appendix A. Australian Health Star Rating graphic and Australian Guide to Healthy Eating}

(a) Health Star Rating system graphic

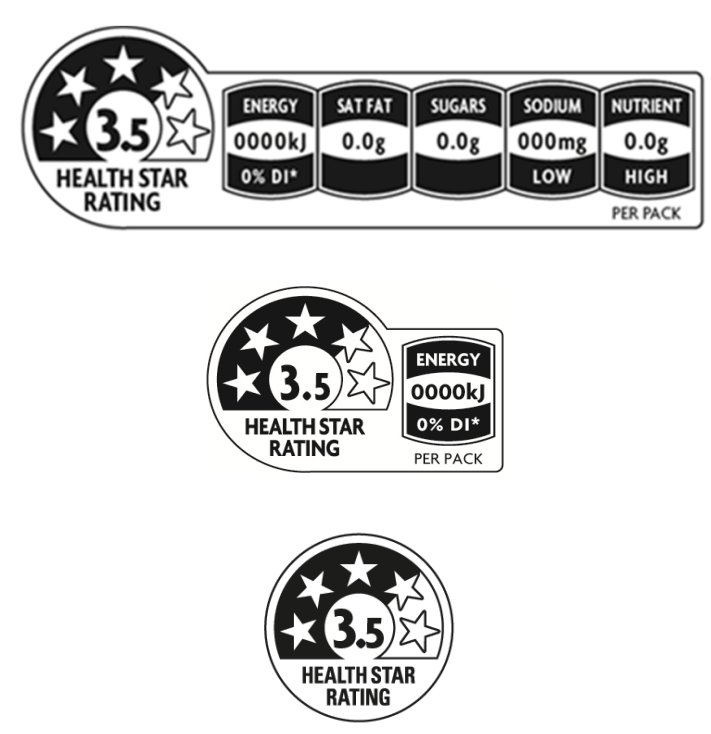

Examples of the HSR graphic to be applied to the front of packaged foods. The label can be applied in multiple acceptable configurations, with and without the addition of energy content and select nutrient information (in addition to the nutrient information panel mandated on the back of pack).

Source: Health Star Rating System Style Guide [14], available at: http:/ / healthstarrating.gov.au / internet/healthstarrating/publishing.nsf/Content/651EEFA223A6A659CA257DA500196046/\$File/ HSR\%20Style\%20Guide-v5.pdf (accessed 8 April 2018).

(b) The Australian Guide to Health Eating (AGHE)

The AGHE is a food selection guide and the primary education and promotional tool in the Australian Government's Eat for Health Program [33]. It converts scientific knowledge of food composition and nutritional requirements for optimal health and wellbeing into a practical guide representing the proportion of ADGs Five Food Groups recommended for consumption each day.

For the purposes of this paper, Five Food Group foods, appearing within the circular 'plate' are referred to as 'core' foods. Foods in the bottom right corner stated to be for consumption 'only sometimes and in small amounts' are illustrative examples of 'discretionary' foods. 


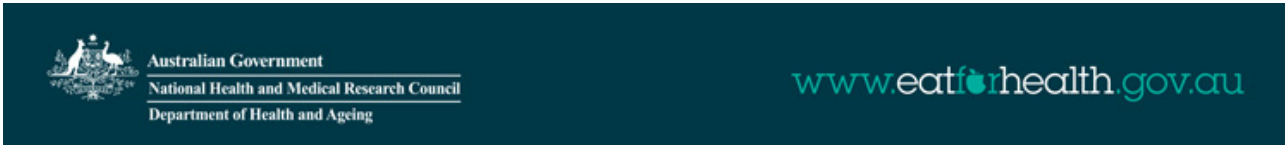

\section{Australian Guide to Healthy Eating}

Enjoy a wide variety of nutritious foods from these five food groups every day. Drink plenty of water.

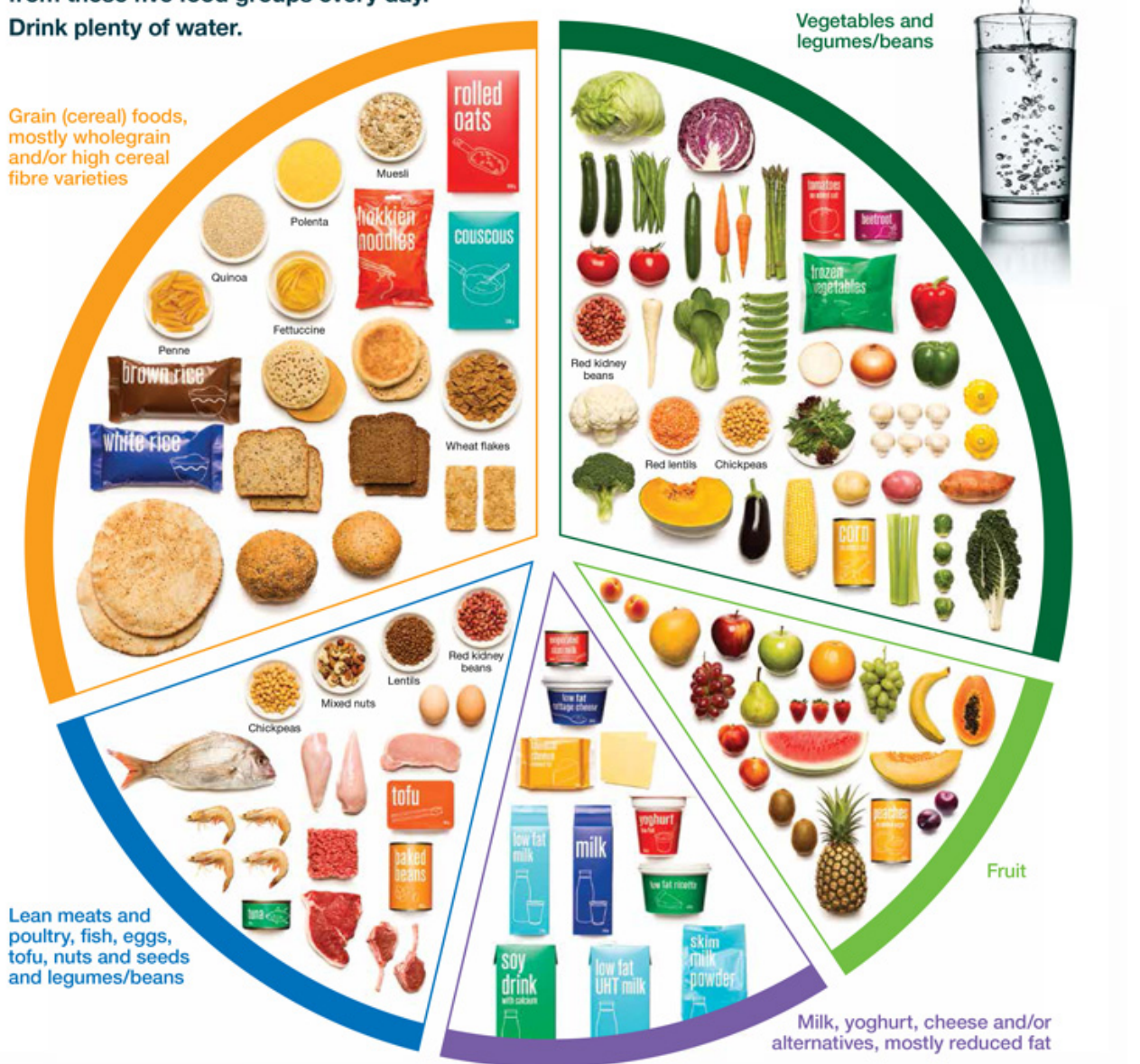

Use small amounts

$\mathbf{m}$
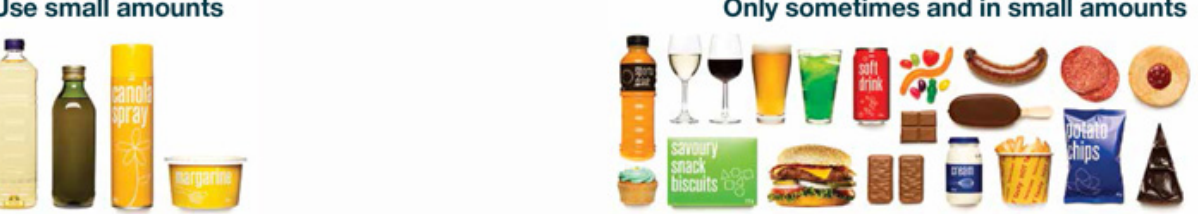

Source: Australian Government Eat for Health Website, available at https:/ /www.eatforhealth. gov.au/guidelines/australian-guide-healthy-eating (accessed 8 April 2018).

Appendix B. Core and Discretionary Outliers by Major Food Group, Category, Traffic Light, ADG/HSR Failure and Policy Recommendation

(a) Core foods receiving HSR $\leq 2.0$ 


\begin{tabular}{|c|c|c|c|c|c|c|c|}
\hline $\begin{array}{l}\text { Major Food Categories (Extracts } \\
\text { of Relevant ADG Text *) }\end{array}$ & $n$ & $\begin{array}{l}\text { Saturated fat } \\
\text { Traffic Light Red }\end{array}$ & $\begin{array}{l}\text { Sodium Traffic } \\
\text { Light Red }\end{array}$ & $\begin{array}{l}\text { Total Sugar } \\
\text { Traffic Light Red }\end{array}$ & $\begin{array}{l}n \text { ADG } \\
\text { Failure }\end{array}$ & $\begin{array}{l}n \text { HSR } \\
\text { Failure }\end{array}$ & Policy Recommendation (Where $n \geq 10$ ) \\
\hline \multicolumn{8}{|l|}{ Bread and Bakery } \\
\hline \multicolumn{8}{|c|}{$\begin{array}{l}\text { Guideline 2: Go for wholegrains. Wholemeal or wholegrain varieties are preferable because they provide more dietary fibre, vitamins and minerals than refined grain (cereal) foods... } \\
\text { Grain (cereal) foods which have high amounts of added saturated fats, added sugars, and/or salt such as most cakes, muffins, pies, pastries and biscuits are not included in this group but are classified 'discretionary' } \\
\text { choices. }\end{array}$} \\
\hline \multicolumn{8}{|l|}{ Biscuits } \\
\hline Savoury biscuits & 76 & 49 & 65 & 8 & 74 & 2 & Review ABS table, including kJ cut-off for biscuits \\
\hline Plain dry biscuits & 49 & 4 & 22 & 0 & 48 & 1 & Review ABS table, including kJ cut-off for biscuits \\
\hline \multicolumn{8}{|l|}{ Bread } \\
\hline Flat bread & 29 & 6 & 24 & 0 & 29 & 1 & None. Less healthy options of core foods \\
\hline Other bread & 20 & 11 & 0 & 18 & 20 & 0 & None. Less healthy options of core foods \\
\hline \multicolumn{8}{|l|}{ Cakes, muffins and pastries } \\
\hline Pancake mix & 17 & 1 & 12 & 6 & 14 & 3 & Review ABS table \\
\hline Crepe mix & 4 & 4 & 1 & 4 & 4 & 0 & \\
\hline
\end{tabular}

\section{Cereal and grain products}

Guideline 2: Go for wholegrains. Wholemeal or wholegrain varieties are preferable because they provide more dietary fibre, vitamins and minerals than refined grain (cereal) foods...

Grain (cereal) foods which have high amounts of added saturated fats, added sugars, and/or salt such as most cakes, muffins, pies, pastries and biscuits are not included in this group but are classified 'discretionary' choices.

\begin{tabular}{|c|c|c|c|c|c|c|c|}
\hline \multicolumn{8}{|l|}{ Noodles } \\
\hline Flavoured noodles & 88 & 79 & 83 & 1 & 88 & 0 & Review ABS table \\
\hline Plain noodles & 6 & 2 & 3 & 0 & 5 & 1 & \\
\hline \multicolumn{8}{|l|}{ Pastas } \\
\hline Packet pastas & 28 & 0 & 28 & 0 & 28 & 0 & Review ABS table \\
\hline Fresh filled pasta & 10 & 10 & 4 & 0 & 10 & 0 & \\
\hline Plain dry pasta & 3 & 0 & 3 & 0 & 3 & 0 & \\
\hline $\begin{array}{l}\text { Other grains and cereals } \\
\text { (e.g., breadcrumbs) }\end{array}$ & 11 & 1 & 11 & 0 & 11 & 0 & Review ABS table \\
\hline
\end{tabular}




\begin{tabular}{|c|c|c|c|c|c|c|c|}
\hline $\begin{array}{l}\text { Major Food Categories (Extracts } \\
\text { of Relevant ADG Text *) }\end{array}$ & $n$ & $\begin{array}{l}\text { Saturated fat } \\
\text { Traffic Light Red }\end{array}$ & $\begin{array}{l}\text { Sodium Traffic } \\
\text { Light Red }\end{array}$ & $\begin{array}{l}\text { Total Sugar } \\
\text { Traffic Light Red }\end{array}$ & $\begin{array}{l}n \text { ADG } \\
\text { Failure }\end{array}$ & $\begin{array}{l}n \text { HSR } \\
\text { Failure }\end{array}$ & Policy Recommendation (Where $n \geq 10$ ) \\
\hline \multicolumn{8}{|l|}{ Breakfast cereals } \\
\hline Muesli & 6 & 6 & 0 & 1 & 6 & 0 & \\
\hline Granola & 4 & 4 & 0 & 2 & 4 & 0 & \\
\hline Flakes & 3 & 0 & 3 & 0 & 3 & 0 & \\
\hline Sweet cereals & 3 & 1 & 0 & 3 & 3 & 0 & \\
\hline Others & 2 & 0 & 0 & 1 & 1 & 1 & \\
\hline \multicolumn{8}{|l|}{ Rice } \\
\hline Packet flavoured rice & 4 & 0 & 4 & 0 & 1 & 0 & \\
\hline Dry rice & 1 & 0 & 1 & 0 & 1 & 0 & \\
\hline Cous cous & 5 & 0 & 5 & 0 & 5 & 0 & \\
\hline Confectionery & - & - & - & - & - & - & \\
\hline \multicolumn{8}{|l|}{ Convenience foods } \\
\hline \multicolumn{8}{|c|}{$\begin{array}{l}\text { Guideline 2: Eat a wide variety of nutritious foods from the five food groups ... } \\
\text { Guideline 3: Limit intake of foods containing saturated fats, added salt, added sugars and }\end{array}$} \\
\hline \multicolumn{8}{|l|}{ Pre-prepared salads and snacks } \\
\hline Antipasto & 14 & 4 & 12 & 1 & 13 & 1 & Review ABS table \\
\hline $\begin{array}{l}\text { Others (salad, sushi, } \\
\text { sandwich) }\end{array}$ & 8 & 3 & 8 & 1 & 8 & 0 & \\
\hline Pizza & 20 & 0 & 18 & 4 & 18 & 0 & Review ABS table. Consider salt cut-off \\
\hline Other frozen foods not specified & 9 & 9 & 3 & 0 & 9 & 0 & \\
\hline Soups & 3 & 0 & 3 & 0 & 3 & 0 & \\
\hline
\end{tabular}




\begin{tabular}{|c|c|c|c|c|c|c|c|}
\hline $\begin{array}{l}\text { Major Food Categories (Extracts } \\
\text { of Relevant ADG Text*) }\end{array}$ & $n$ & $\begin{array}{l}\text { Saturated fat } \\
\text { Traffic Light Red }\end{array}$ & $\begin{array}{l}\text { Sodium Traffic } \\
\text { Light Red }\end{array}$ & $\begin{array}{l}\text { Total Sugar } \\
\text { Traffic Light Red }\end{array}$ & $\begin{array}{l}n \text { ADG } \\
\text { Failure }\end{array}$ & $\begin{array}{l}n \text { HSR } \\
\text { Failure }\end{array}$ & Policy Recommendation (Where $n \geq 10$ ) \\
\hline \multicolumn{8}{|l|}{ Dairy } \\
\hline \multicolumn{8}{|c|}{$\begin{array}{l}\text { Guideline 2: Include milk, yoghurt and cheese and/or alternatives-mostly reduced fat } \\
\text { Full fat cheeses should be limited to 2-3 serves per week, and varieties which are lower in salt are preferable }\end{array}$} \\
\hline \multicolumn{8}{|l|}{ Cheese } \\
\hline Hard and semi-hard cheeses & 283 & 283 & 270 & 0 & 283 & 0 & Review ABS table, core status given salt and sat fat \\
\hline Soft cheeses & 177 & 177 & 73 & 0 & 177 & 0 & Review ABS table, core status given salt and sat fat \\
\hline Processed cheeses & 30 & 30 & 30 & 0 & 30 & 0 & Review ABS table, core status given salt and sat fat \\
\hline Sheep/goat cheese & 13 & 13 & 12 & 0 & 13 & 0 & Review ABS table, core status given salt and sat fat \\
\hline Soy cheese & 9 & 9 & 9 & 0 & 9 & 0 & Review ABS table, core status given salt and sat fat \\
\hline \multicolumn{8}{|l|}{ Yoghurt } \\
\hline Yoghurt with fruit & 204 & 82 & 0 & 145 & 163 & 41 & $\begin{array}{l}\text { Review ABS table, core status given sat fat and } \\
\text { sugar } \\
\text { HSR failures suggest review sugar, added sugars }\end{array}$ \\
\hline Flavoured yoghurt & 105 & 64 & 0 & 75 & 95 & 10 & $\begin{array}{l}\text { Review ABS table, core status given sat fat and } \\
\text { sugar } \\
\text { HSR failures suggest review sugar, added sugars }\end{array}$ \\
\hline Natural yoghurts & 57 & 53 & 0 & 6 & 55 & 2 & $\begin{array}{l}\text { Review ABS table, core status given sat fat and } \\
\text { sugar }\end{array}$ \\
\hline Non-dairy yoghurts (coconut) & 23 & 23 & 0 & 0 & 23 & 0 & Review ABS table (Coconut products) \\
\hline Yoghurt mixes & 24 & 6 & 0 & 22 & 22 & 2 & HSR impacted by 'as prepared' \\
\hline $\begin{array}{l}\text { Yoghurts with muesli or } \\
\text { non-fruit additions }\end{array}$ & 19 & 11 & 0 & 18 & 19 & 0 & $\begin{array}{l}\text { Review ABS table, core status given sat fat and } \\
\text { sugar } \\
\text { Review sugar, added sugars in HSR algorithm }\end{array}$ \\
\hline Drinking yoghurt & 1 & 0 & 0 & 0 & 0 & 1 & \\
\hline
\end{tabular}




\begin{tabular}{|c|c|c|c|c|c|c|c|}
\hline $\begin{array}{l}\text { Major Food Categories (Extracts } \\
\text { of Relevant ADG Text }{ }^{*} \text { ) }\end{array}$ & $n$ & $\begin{array}{l}\text { Saturated fat } \\
\text { Traffic Light Red }\end{array}$ & $\begin{array}{l}\text { Sodium Traffic } \\
\text { Light Red }\end{array}$ & $\begin{array}{l}\text { Total Sugar } \\
\text { Traffic Light Red }\end{array}$ & $\begin{array}{l}n \text { ADG } \\
\text { Failure }\end{array}$ & $\begin{array}{l}n \text { HSR } \\
\text { Failure }\end{array}$ & Policy Recommendation (Where $n \geq 10$ ) \\
\hline \multicolumn{8}{|l|}{ Milks } \\
\hline Coconut milks and creams & 79 & 79 & 0 & 0 & 79 & 0 & Review ABS table (Coconut products) \\
\hline Dairy milks & 19 & 15 & 0 & 15 & 19 & 0 & $\begin{array}{l}\text { Review ABS table, core status given sat fat and } \\
\text { sugar } \\
\text { Review sugar, added sugars in HSR algorithm }\end{array}$ \\
\hline Other milks & 2 & 2 & 2 & 0 & 2 & 0 & \\
\hline \multicolumn{8}{|l|}{ Cream products } \\
\hline Mascarpone & 9 & 9 & 0 & 0 & 9 & 0 & \\
\hline Desserts (crème caramel) & 2 & 2 & 0 & 2 & 2 & 0 & \\
\hline
\end{tabular}

Edible oils and oil emulsions

Guideline 3: Limit intake of foods containing saturated fats, added salt, added sugars and alcohol.

Replace high fat foods which contain predominately saturated fats such as butter, cream, cooking margarine, coconut and palm oil with foods which contain predominately polyunsaturated and monounsaturated fats such as oils, spreads, nut butters/pastes and avocado.

\begin{tabular}{|c|c|c|c|c|c|c|c|}
\hline Coconut oils & 43 & 43 & 0 & 0 & 43 & 0 & Review ABS table. ADG text suggest avoid. \\
\hline Cooking oils (e.g., rice bran) & 16 & 16 & 0 & 0 & 16 & 0 & Review ABS table \\
\hline Edible oils (e.g., margarine) & 11 & 11 & 0 & 0 & 11 & 0 & Review ABS table \\
\hline $\begin{array}{l}\text { Cooking spray oils (e.g., } \\
\text { coconut) }\end{array}$ & 3 & 3 & 0 & 0 & 3 & 0 & \\
\hline Eggs & - & - & - & - & - & - & \\
\hline
\end{tabular}

Guideline 2: Choose lean meat and poultry, fish, eggs and/or plant-based alternatives

\section{Fish and fish products}

Guideline 2: Choose lean meat and poultry, fish, eggs and/or plant-based alternatives

Fresh, frozen and canned varieties of meats, poultry or fish are all suitable, but choose varieties that are low in salt and saturated fat. Processed meats such as salami, mettwurst, bacon and ham are not part of this food group. They are classified as discretionary choices because they are high in saturated fat and/or salt.

\begin{tabular}{llllllll}
\hline Chilled fish & & & & & \\
\hline Smoked salmon & 82 & 1 & 82 & 0 & 82 & 0 & Review ABS table \\
\hline Other chilled raw fish & 7 & 3 & 4 & 1 & 6 & 1
\end{tabular}




\begin{tabular}{|c|c|c|c|c|c|c|c|}
\hline $\begin{array}{l}\text { Major Food Categories (Extracts } \\
\text { of Relevant ADG Text *) }\end{array}$ & $n$ & $\begin{array}{l}\text { Saturated fat } \\
\text { Traffic Light Red }\end{array}$ & $\begin{array}{l}\text { Sodium Traffic } \\
\text { Light Red }\end{array}$ & $\begin{array}{l}\text { Total Sugar } \\
\text { Traffic Light Red }\end{array}$ & $\begin{array}{l}n \text { ADG } \\
\text { Failure }\end{array}$ & $\begin{array}{l}n \text { HSR } \\
\text { Failure }\end{array}$ & Policy Recommendation (Where $n \geq 10$ ) \\
\hline \multicolumn{8}{|l|}{ Canned fish } \\
\hline Anchovies & 24 & 2 & 24 & 0 & 24 & 0 & Review ABS table \\
\hline Canned herring & 9 & 0 & 8 & 0 & 8 & 0 & \\
\hline Canned salmon & 5 & 0 & 3 & 0 & 3 & 2 & \\
\hline Other canned fish & 8 & 5 & 4 & 0 & 8 & 0 & \\
\hline $\begin{array}{l}\text { Other fish products not } \\
\text { specified }\end{array}$ & 28 & 9 & 24 & 0 & 27 & 1 & Review ABS table \\
\hline
\end{tabular}

\section{Fruit and vegetables}

Guideline 2: Tuck into vegetables and fruit. Fresh, frozen, canned or dried varieties of vegetables and fruit are all suitable foods. Check the ingredients list and choose varieties of canned vegetables without added salt and canned fruit in natural juice, not syrup

Vegetables and fruit to limit: ... dried fruit can also stick to the teeth and increase the risk of tooth decay. For this reason ... dried fruit should be consumed only occasionally and in small amounts.

The intake of some salted, dried, fermented or pickled vegetables has been associated with increased risk of some cancers, so intake of these foods should be limited. Also limit intake of fried vegetables such as potato and vegetable chips and crisps, which add extra kilojoules and salt. Chips and crisps are included in 'discretionary choices'

\begin{tabular}{|c|c|c|c|c|c|c|c|}
\hline Fruit & & & & & & & \\
\hline Dried fruit & 54 & 50 & 3 & 43 & 54 & 0 & Review ABS table and ADG text on dried fruit \\
\hline $\begin{array}{l}\text { Fruit-based products (e.g., } \\
\text { date balls) }\end{array}$ & 20 & 5 & 1 & 18 & 20 & 0 & Review ABS table and ADG text on dried fruit \\
\hline Coconut chunks & 10 & 10 & 4 & 4 & 10 & 0 & Review ABS table (coconut products) \\
\hline Fruit in syrup & 3 & 3 & 0 & 3 & 3 & 0 & \\
\hline \multicolumn{8}{|l|}{ Vegetables } \\
\hline Sundried tomatoes & 6 & 1 & 6 & 4 & 6 & 0 & \\
\hline $\begin{array}{r}\text { Other veg. products } \\
\text { (namkeem, fried shallot) }\end{array}$ & 3 & 2 & 1 & 0 & 3 & 0 & \\
\hline \multicolumn{8}{|l|}{ Nuts and seeds } \\
\hline Nuts, salted and sweet-coated & 6 & 6 & 3 & 3 & 6 & 0 & \\
\hline \multicolumn{8}{|l|}{ Herbs and spices } \\
\hline Herb pastes & 32 & 0 & 32 & 14 & 32 & 0 & Review ABS table. Potential new category \\
\hline Spice mixes & 43 & 9 & 38 & 5 & 43 & 0 & Review ABS table. HSR impacted by as prepared. \\
\hline Curry powders & 4 & 0 & 4 & 0 & 4 & 0 & \\
\hline
\end{tabular}




\begin{tabular}{|c|c|c|c|c|c|c|c|}
\hline $\begin{array}{l}\text { Major Food Categories (Extracts } \\
\text { of Relevant ADG Text }{ }^{*} \text { ) }\end{array}$ & $n$ & $\begin{array}{l}\text { Saturated fat } \\
\text { Traffic Light Red }\end{array}$ & $\begin{array}{l}\text { Sodium Traffic } \\
\text { Light Red }\end{array}$ & $\begin{array}{l}\text { Total Sugar } \\
\text { Traffic Light Red }\end{array}$ & $\begin{array}{l}n \text { ADG } \\
\text { Failure }\end{array}$ & $\begin{array}{l}n \text { HSR } \\
\text { Failure }\end{array}$ & Policy Recommendation (Where $n \geq 10$ ) \\
\hline
\end{tabular}

Guideline 2: Choose lean meat and poultry, fish, eggs and/or plant-based alternatives

Fresh, frozen and canned varieties of meats, poultry or fish are all suitable, but choose varieties that are low in salt and saturated fat. Processed meats such as salami, mettwurst, bacon and ham are not part of this

food group. They are classified as discretionary choices because they are high in saturated fat and/or salt.

\begin{tabular}{|c|c|c|c|c|c|c|c|}
\hline Pate and meat spreads & 51 & 49 & 17 & 0 & 51 & 0 & Review ABS table \\
\hline Raw flavoured meats & 41 & 38 & 20 & 2 & 41 & 0 & Review ABS table. Further meat categories needed \\
\hline Sausages and hot dogs & 37 & 0 & 37 & 1 & 37 & 0 & Review ABS table. Consider salt cut-off \\
\hline Meat not otherwise specified & 15 & 10 & 12 & 0 & 15 & 0 & Review ABS table. Further meat categories needed \\
\hline Raw flavoured meats & 8 & 3 & 6 & 0 & 8 & 0 & \\
\hline $\begin{array}{l}\text { Uncoated frozen/chilled } \\
\text { processed meat }\end{array}$ & 6 & 2 & 5 & 0 & 6 & 0 & \\
\hline Kebabs & 3 & 2 & 2 & 0 & 3 & 0 & \\
\hline Burgers & 3 & 0 & 3 & 0 & 3 & 0 & \\
\hline
\end{tabular}

Non-alcoholic beverages

Guideline 2: Tea and coffee provide water, although they are not suitable for young children and large quantities can have unwanted stimulant effects in some people.

Guideline 3: Limit intake of foods containing saturated fats, added salt, added sugars and alcohol.

\begin{tabular}{|c|c|c|c|c|c|c|c|}
\hline Teas (not plain) & 42 & 2 & 0 & 9 & 10 & 32 & $\begin{array}{l}\text { Review ABS table. } \\
\text { HSR failures suggest review added sugars }\end{array}$ \\
\hline Fruit juices & 4 & 0 & 0 & 3 & 3 & 1 & \\
\hline \multicolumn{8}{|c|}{$\begin{array}{l}\text { Sauces, dressings, dips and } \\
\text { spreads }\end{array}$} \\
\hline \multicolumn{8}{|c|}{ Guideline 3: Limit intake of foods high in saturated fats, added salt, added sugars and alcohol. } \\
\hline Vinegars & 11 & 0 & 4 & 8 & 11 & 0 & Review ABS table \\
\hline \multicolumn{8}{|l|}{ Special foods } \\
\hline \multicolumn{8}{|l|}{ Not specifically covered } \\
\hline Meal replacements & 75 & 21 & 46 & 70 & 75 & 0 & $\begin{array}{l}\text { Review ABS table and eligibility for HSR. } \\
\text { HSR impacted by 'as prepared' }\end{array}$ \\
\hline
\end{tabular}




\begin{tabular}{|c|c|c|c|c|c|c|c|}
\hline $\begin{array}{l}\text { Major Food Categories (Extracts } \\
\text { of Relevant ADG Text*) }\end{array}$ & $n$ & $\begin{array}{l}\text { Saturated fat } \\
\text { Traffic Light Red }\end{array}$ & $\begin{array}{l}\text { Sodium Traffic } \\
\text { Light Red }\end{array}$ & $\begin{array}{l}\text { Total Sugar } \\
\text { Traffic Light Red }\end{array}$ & $\begin{array}{l}n \text { ADG } \\
\text { Failure }\end{array}$ & $\begin{array}{l}n \text { HSR } \\
\text { Failure }\end{array}$ & Policy Recommendation (Where $n \geq 10$ ) \\
\hline \multicolumn{8}{|l|}{ Sugars, honey and syrups } \\
\hline \multicolumn{8}{|c|}{$\begin{array}{l}\text { Guideline 3: Limit intake of foods high in saturated fats, added salt, added sugars and alcohol. } \\
\text { Foods and drinks that are artificially sweetened can provide a useful alternative to those high in added sugars. }\end{array}$} \\
\hline Sweeteners & 20 & 0 & 0 & 20 & 20 & 0 & $\begin{array}{l}\text { Review ABS table and ADG text on artificial } \\
\text { sweeteners }\end{array}$ \\
\hline TOTAL & 221 & 1136 & 1159 & 538 & 2116 & 103 & \\
\hline
\end{tabular}

${ }^{*}$ For the purposes of this Appendix we have extracted direct statements from the Australian Dietary Guidelines Summary Document: https://www.nhmrc.gov.au/_files_nhmrc/file/ your_health/healthy/nutrition/n55a_australian_dietary_guidelines_summary_131014_1.pdf.

(b) Discretionary Outliers with HSR $\geq 3.5$

\begin{tabular}{|c|c|c|c|c|c|c|c|}
\hline $\begin{array}{l}\text { Major Food Categories (Extracts } \\
\text { of Relevant ADG text*) }\end{array}$ & $\mathbf{n}$ & $\begin{array}{l}\text { Saturated Fat } \\
\text { Traffic Light Red }\end{array}$ & $\begin{array}{l}\text { Sodium Traffic } \\
\text { Light Red }\end{array}$ & $\begin{array}{l}\text { Total Sugar } \\
\text { Traffic Light Red }\end{array}$ & $\begin{array}{l}n \\
\text { ADG Failure }\end{array}$ & $\begin{array}{l}n \\
\text { HSR Failure }\end{array}$ & Policy Recommendation (Where $n \geq 10$ ) \\
\hline \multicolumn{8}{|l|}{ Breads and bakery } \\
\hline \multicolumn{8}{|c|}{$\begin{array}{l}\text { Guideline 2: Go for wholegrains. Wholemeal or wholegrain varieties are preferable because they provide more dietary fibre, vitamins and minerals than refined grain (cereal) foods... } \\
\text { Grain (cereal) foods which have high amounts of added saturated fats, added sugars, and/or salt such as most cakes, muffins, pies, pastries and biscuits are not included in this group but are classified 'discretionar. } \\
\text { choices. }\end{array}$} \\
\hline \multicolumn{8}{|l|}{ Bread } \\
\hline Savoury breads & 36 & 1 & 2 & 0 & 33 & 3 & Mostly healthier options of discretionary foods \\
\hline Sweet breads & 17 & 0 & 1 & 4 & 12 & 5 & Mostly healthier options of discretionary foods \\
\hline $\begin{array}{l}\text { Others (garlic bread, ice } \\
\text { cream cone, taco shell) }\end{array}$ & 25 & 0 & 0 & 0 & 25 & 0 & None. Healthier options of discretionary foods \\
\hline
\end{tabular}




\begin{tabular}{|c|c|c|c|c|c|c|c|}
\hline $\begin{array}{l}\text { Major Food Categories (Extracts } \\
\text { of Relevant ADG text }{ }^{*} \text { ) }\end{array}$ & $\mathbf{n}$ & $\begin{array}{l}\text { Saturated Fat } \\
\text { Traffic Light Red }\end{array}$ & $\begin{array}{l}\text { Sodium Traffic } \\
\text { Light Red }\end{array}$ & $\begin{array}{l}\text { Total Sugar } \\
\text { Traffic Light Red }\end{array}$ & $\begin{array}{l}n \\
\text { ADG Failure }\end{array}$ & $\begin{array}{l}n \\
\text { HSR Failure }\end{array}$ & Policy Recommendation (Where $n \geq 10$ ) \\
\hline \multicolumn{8}{|l|}{ Biscuits } \\
\hline $\begin{array}{l}\text { Savoury biscuits (crackers } \\
\text { and crispbreads) }\end{array}$ & 20 & 0 & 2 & 1 & 17 & 3 & $\begin{array}{l}\text { Mostly healthier options of discretionary foods } \\
\text { Review ABS table and kJ cut-off savoury biscuits }\end{array}$ \\
\hline $\begin{array}{l}\text { Sweet unfilled biscuits (plain, } \\
\text { fruit and nut) }\end{array}$ & 17 & 0 & 0 & 5 & 12 & 5 & Mostly healthier versions of discretionary foods \\
\hline Plain dry biscuits & 12 & 0 & 0 & 0 & 12 & 0 & None. Healthier options of discretionary foods \\
\hline \multicolumn{8}{|l|}{ Cakes, Muffins and Pastries } \\
\hline Pastries (filo sheets, quiches) & 24 & 6 & 1 & 0 & 17 & 7 & Mostly healthier versions of discretionary foods \\
\hline Cake mixes & 8 & 0 & 1 & 0 & 7 & 1 & \\
\hline Cakes & 8 & 0 & 0 & 1 & 7 & 1 & \\
\hline
\end{tabular}

\section{Cereal and Grain Products}

Guideline 2: Go for wholegrains. Wholemeal or wholegrain varieties are preferable because they provide more dietary fibre, vitamins and minerals than refined grain (cereal) foods...

Grain (cereal) foods which have high amounts of added saturated fats, added sugars, and/or salt such as most cakes, muffins, pies, pastries and biscuits are not included in this group but are classified 'discretionary' choices.

\begin{tabular}{|c|c|c|c|c|c|c|c|}
\hline \multicolumn{8}{|l|}{ Cereal and nut-based bars } \\
\hline Cereal bars & 158 & 1 & 1 & 22 & 134 & 24 & $\begin{array}{l}\text { Mostly healthier versions of discretionary foods } \\
\text { HSR failures suggest review sugar, added sugars }\end{array}$ \\
\hline Nut-based bars & 46 & 3 & 0 & 12 & 32 & 14 & $\begin{array}{l}\text { Mostly healthier versions of discretionary foods } \\
\text { HSR failures suggest review sugar, added sugars }\end{array}$ \\
\hline Puff-based bars & 9 & 0 & 0 & 1 & 8 & 1 & \\
\hline \multicolumn{8}{|l|}{ Ready-to-eat breakfast cereals } \\
\hline $\begin{array}{l}\text { Sweet, cocoa-based and puff } \\
\text { cereals }\end{array}$ & 38 & 0 & 0 & 25 & 13 & 25 & $\begin{array}{l}\text { HSR failures suggest review sugar, added sugars } \\
\text { Review ABS table. Sugar cut-off for breakfast } \\
\text { cereals ( } 30 / 100 \mathrm{~g}, 35 / 100 \mathrm{~g} \text { with fruit) already high. }\end{array}$ \\
\hline Breakfast cookie/rusk & 9 & 0 & 0 & 1 & 8 & 1 & \\
\hline \multicolumn{8}{|l|}{ Other cereal products } \\
\hline Stuffing mixes & 2 & 0 & 0 & 0 & 2 & 0 & Healthier versions of discretionary foods \\
\hline
\end{tabular}




\begin{tabular}{|c|c|c|c|c|c|c|c|}
\hline $\begin{array}{l}\text { Major Food Categories (Extracts } \\
\text { of Relevant ADG text }{ }^{*} \text { ) }\end{array}$ & $\mathbf{n}$ & $\begin{array}{l}\text { Saturated Fat } \\
\text { Traffic Light Red }\end{array}$ & $\begin{array}{l}\text { Sodium Traffic } \\
\text { Light Red }\end{array}$ & $\begin{array}{l}\text { Total Sugar } \\
\text { Traffic Light Red }\end{array}$ & $\begin{array}{l}n \\
\text { ADG Failure }\end{array}$ & $\begin{array}{l}n \\
\text { HSR Failure }\end{array}$ & Policy Recommendation (Where $n \geq 10$ ) \\
\hline \multicolumn{8}{|l|}{ Confectionery } \\
\hline \multicolumn{8}{|c|}{$\begin{array}{l}\text { Guideline 3: Limit intake of foods high in saturated fats, added salt, added sugars and alcohol. } \\
\text { Limit intake of foods and drinks containing added sugars such as confectionary (sic) }\end{array}$} \\
\hline Chewing gums & 75 & 0 & 0 & 0 & 75 & 0 & Review application of HSR \\
\hline Jelly & 63 & 0 & 0 & 7 & 57 & 7 & $\begin{array}{l}\text { Mostly healthier versions of discretionary foods } \\
\text { HSR failures suggest review sugar, added sugars }\end{array}$ \\
\hline Chocolate and sweets & 36 & 4 & 0 & 1 & 31 & 5 & $\begin{array}{l}\text { Mostly healthier versions of discretionary foods } \\
\text { HSR failures suggest review saturated fat }\end{array}$ \\
\hline
\end{tabular}

Guideline 2: Eat a wide variety of nutritious foods from the five food groups...

Guideline 3: Limit intake of foods containing saturated fats, added salt, added sugars and alcohol.

$$
\text { Ready meals }
$$

\begin{tabular}{|c|c|c|c|c|c|c|c|}
\hline Frozen ready meals & 180 & 22 & 24 & 7 & 136 & 44 & $\begin{array}{l}\text { Many healthier versions of discretionary foods } \\
\text { Review ABS table: complexity of classification } \\
\text { highlights diversity of products. } \\
\text { HSR failures suggest review salt and saturated fat }\end{array}$ \\
\hline Ambient ready meals & 127 & 10 & 22 & 4 & 98 & 29 & As above \\
\hline Chilled ready meals & 97 & 50 & 21 & 6 & 40 & 57 & As above \\
\hline Others (meal kits) & 8 & 2 & 3 & 1 & 4 & 4 & \\
\hline \multicolumn{8}{|l|}{ Soup } \\
\hline $\begin{array}{l}\text { Dry Soup mixes (as prepared } \\
\text { with water) }\end{array}$ & 96 & 0 & 0 & 2 & 94 & 2 & $\begin{array}{l}\text { ABS table review } \\
\text { HSR impacted by 'as prepared' }\end{array}$ \\
\hline
\end{tabular}

\section{Dairy}

Guideline 2: Include milk, yoghurt and cheese and/or alternatives-mostly reduced fat

Some other milk products, such as ice-cream, can be relatively high in saturated fat and added sugars, so are classified under discretionary choices, together with cream and butter.

\begin{tabular}{llllllll}
\hline Ice creams and edible ices & & & & & \\
\hline Edible ices & 28 & 0 & 0 & 2 & 26 & 2 & 1 \\
\hline Ice creams & 16 & 0 & 0 & 0 & 2 & 2 & 2 \\
\hline Frozen yoghurt & 4 & 0 & 0 & 0 & 2 & 0 \\
\hline Soy-based ice cream & 2 & 0 & None. Healthier options of discretionary foods & \\
\hline
\end{tabular}




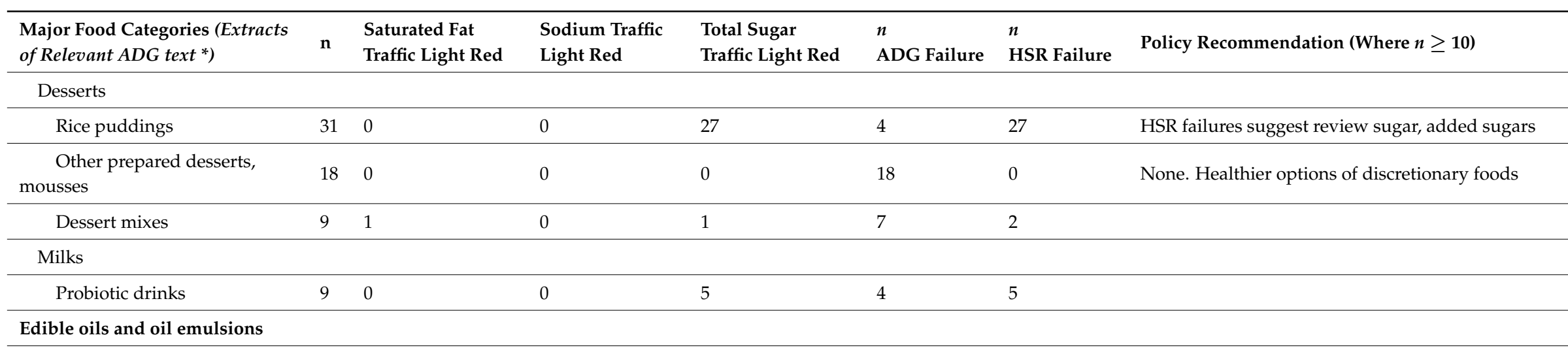

Guideline 3: Limit intake of foods containing saturated fats, added salt, added sugars and alcohol.

Replace high fat foods which contain predominately saturated fats such as butter, cream, cooking margarine, coconut and palm oil with foods which contain predominately polyunsaturated and monounsaturated fats such as oils, spreads, nut butters/pastes and avocado.

\begin{tabular}{lllllll}
\hline Edible oils & 2 & 1 & 0 & 1 & 0 & 2 \\
\hline Eggs & - & - & - & - & - & - \\
\hline Fish and fish products & & & & & \\
\hline
\end{tabular}

Guideline 2: Choose lean meat and poultry, fish, eggs and/or plant-based alternatives

Fresh, frozen and canned varieties of meats, poultry or fish are all suitable, but choose varieties that are low in salt and saturated fat. Processed meats such as salami, mettwurst, bacon and ham are not part of this food group. They are classified as discretionary choices because they are high in saturated fat and/or salt.

\begin{tabular}{cllllll}
\hline Processed fish & 219 & 0 & 13 & 0 & 131 & 13
\end{tabular}

\section{Fruit and vegetables}

Guideline 2: Tuck into vegetables and fruit. Fresh, frozen, canned or dried varieties of vegetables and fruit are all suitable foods. Check the ingredients list and choose varieties of canned vegetables without added salt and canned fruit in natural juice, not syrup.

Vegetables and fruit to limit: ... dried fruit can also stick to the teeth and increase the risk of tooth decay. For this reason ... dried fruit should be consumed only occasionally and in small amounts. The intake of some salted, dried, fermented or pickled vegetables has been associated with increased risk of some cancers, so intake of these foods should be limited. Also limit intake of fried vegetables such as potato and vegetable chips and crisps, which add extra kilojoules and salt. Chips and crisps are included in 'discretionary choices'.

\begin{tabular}{lllllll}
\hline Vegetables & & & & & \\
\hline Pickled vegetables & 155 & 1 & 35 & 3 & 38 & $\begin{array}{l}\text { Many healthier options of discretionary foods } \\
\text { HSR failures suggest review salt }\end{array}$ \\
\hline Frozen potato products & 125 & 1 & 0 & 0 & 124 & $\begin{array}{l}\text { Review ABS table 'Potato Products' } \\
\text { Healthier options of discretionary foods }\end{array}$ \\
\hline
\end{tabular}




\begin{tabular}{|c|c|c|c|c|c|c|c|}
\hline $\begin{array}{l}\text { Major Food Categories (Extracts } \\
\text { of Relevant ADG text }{ }^{*} \text { ) }\end{array}$ & $\mathbf{n}$ & $\begin{array}{l}\text { Saturated Fat } \\
\text { Traffic Light Red }\end{array}$ & $\begin{array}{l}\text { Sodium Traffic } \\
\text { Light Red }\end{array}$ & $\begin{array}{l}\text { Total Sugar } \\
\text { Traffic Light Red }\end{array}$ & $\begin{array}{l}n \\
\text { ADG Failure }\end{array}$ & $\begin{array}{l}n \\
\text { HSR Failure }\end{array}$ & Policy Recommendation (Where $n \geq 10$ ) \\
\hline \multicolumn{8}{|l|}{ Fruit } \\
\hline Fruit bars and bites & 52 & 4 & 0 & 46 & 5 & 47 & HSR failures suggest review sugar, added sugars \\
\hline Jams and marmalades & 4 & 0 & 0 & 0 & 4 & 0 & \\
\hline Seasonings & 11 & 0 & 0 & 0 & 11 & 0 & Review ABS table \\
\hline \multicolumn{8}{|l|}{ Meat and meat products } \\
\hline \multicolumn{8}{|c|}{$\begin{array}{l}\text { Guideline 2: Choose lean meat and poultry, fish, eggs and/or plant-based alternatives. } \\
\text { Fresh, frozen and canned varieties of meats, poultry or fish are all suitable, but choose varieties that are low in salt and saturated fat. Processed meats such as salami, mettwurst, bacon and ham are not part of thi } \\
\text { food group. They are classified as discretionary choices because they are high in saturated fat and/or salt. }\end{array}$} \\
\hline \multicolumn{8}{|l|}{ Frozen and chilled meats } \\
\hline $\begin{array}{l}\text { Coated } / \text { breaded / frozen } \\
\text { meats }\end{array}$ & 152 & 8 & 17 & 0 & 128 & 24 & $\begin{array}{l}\text { Mostly healthier options of discretionary foods } \\
\text { HSR failures suggest review salt, saturated fat }\end{array}$ \\
\hline Meat with pastry & 57 & 36 & 6 & 0 & 20 & 37 & $\begin{array}{l}\text { Some healthier options of discretionary foods } \\
\text { HSR failures suggest review saturated fat, salt }\end{array}$ \\
\hline Sliced meats & 104 & 0 & 84 & 0 & 20 & 84 & $\begin{array}{l}\text { Some healthier options of discretionary foods } \\
\text { HSR failures suggest review salt }\end{array}$ \\
\hline Canned meats & 46 & 1 & 11 & 0 & 34 & 12 & $\begin{array}{l}\text { Many healthier options of discretionary foods } \\
\text { HSR failures suggest review salt }\end{array}$ \\
\hline Salami and cured meats & 8 & 2 & 1 & 0 & 5 & 3 & \\
\hline Burgers & 7 & 7 & 0 & 0 & 0 & 7 & \\
\hline Dried meats & 6 & 0 & 0 & 0 & 6 & 0 & \\
\hline Bacon & 4 & 0 & 3 & 0 & 1 & 3 & \\
\hline \multicolumn{8}{|l|}{ Non-alcoholic beverages } \\
\hline \multicolumn{8}{|c|}{$\begin{array}{l}\text { Water is essential for life. Choose water instead of drinks with added sugars or alcohol ... Consumption of drinks with added sugars, such as soft drinks and cordials, fruit drinks, vitamin waters, energy and sports } \\
\text { drinks can increase risk of excessive weight gain in both children and adults. Water has an advantage over these drinks, and also over fruit juice and artificially sweetened soft drinks... }\end{array}$} \\
\hline Hot chocolate, milk flavourings & 22 & 0 & 0 & 15 & 15 & 7 & $\begin{array}{l}\text { HSR impacted by as prepared } \\
\text { HSR failures suggest review sugar, added sugars }\end{array}$ \\
\hline Beverage mixes & 6 & 0 & 0 & 1 & 5 & 1 & \\
\hline Electrolyte drinks & 2 & 0 & 0 & 0 & 2 & 0 & \\
\hline
\end{tabular}




\begin{tabular}{|c|c|c|c|c|c|c|c|}
\hline $\begin{array}{l}\text { Major Food Categories (Extracts of } \\
\text { Relevant ADG text }{ }^{*} \text { ) }\end{array}$ & $\mathbf{n}$ & $\begin{array}{l}\text { Saturated Fat } \\
\text { Traffic Light Red }\end{array}$ & $\begin{array}{l}\text { Sodium Traffic } \\
\text { Light Red }\end{array}$ & $\begin{array}{l}\text { Total Sugar } \\
\text { Traffic Light Red }\end{array}$ & $\begin{array}{l}n \\
\text { ADG Failure }\end{array}$ & $\begin{array}{l}n \\
\text { HSR Failure }\end{array}$ & Policy Recommendation (Where $n \geq 10$ ) \\
\hline \multicolumn{8}{|l|}{ Sauces, dressings, spreads and dips } \\
\hline \multicolumn{8}{|c|}{$\begin{array}{l}\text { Guideline 3: Limit intake of foods containing saturated fats, added salt, added sugars and alcohol. } \\
\text { Tips to eat less saturated fat: ... cut down on dishes with cream, buttery or creamy sauces or fatty gravy, instead choose tomato-based dishes. } \\
\text { Limit foods high in added sugars including ... sweetened sauces and dressings ... }\end{array}$} \\
\hline \multicolumn{8}{|l|}{ Sauces } \\
\hline \multicolumn{8}{|l|}{ Pasta sauces } \\
\hline Tomato-based pasta sauces & 389 & 2 & 15 & 1 & 371 & 18 & $\begin{array}{l}\text { Mostly healthier options of discretionary foods } \\
\text { Review ABS table, tomato sauces home vs } \\
\text { commercial } \\
\text { HSR failures suggest review salt }\end{array}$ \\
\hline Cream-based pasta sauces & 37 & 4 & 4 & 0 & 29 & 8 & $\begin{array}{l}\text { Many healthier options of discretionary foods } \\
\text { HSR failures suggest review saturated fat, salt }\end{array}$ \\
\hline Meat-based pasta sauces & 15 & 0 & 1 & 0 & 14 & 1 & $\begin{array}{l}\text { None. Mostly healthier options of discretionary } \\
\text { foods }\end{array}$ \\
\hline \multicolumn{8}{|l|}{ Meal-based sauces } \\
\hline Ambient meal-based sauces & 84 & 4 & 1 & 5 & 75 & 9 & $\begin{array}{l}\text { Mostly healthier options of discretionary foods } \\
\text { HSR impacted by as prepared }\end{array}$ \\
\hline Powdered meal-based sauces & 44 & 4 & 7 & 1 & 33 & 11 & $\begin{array}{l}\text { Many healthier options of discretionary foods } \\
\text { HSR impacted by as prepared }\end{array}$ \\
\hline Liquid recipe bases & 41 & 1 & 14 & 0 & 26 & 15 & $\begin{array}{l}\text { Many healthier options of discretionary foods } \\
\text { HSR impacted by as prepared } \\
\text { HSR failures suggest review salt }\end{array}$ \\
\hline Curry pastes & 11 & 0 & 1 & 1 & 9 & 2 & Mostly healthier options of discretionary foods \\
\hline Gravies and stocks & 16 & 0 & 0 & 0 & 16 & 0 & $\begin{array}{l}\text { Mostly healthier options of discretionary foods } \\
\text { HSR impacted by as prepared }\end{array}$ \\
\hline Table sauces & 54 & 0 & 11 & 15 & 28 & 26 & $\begin{array}{l}\text { Some healthier options of discretionary foods } \\
\text { HSR failures suggest review salt, sugar, added } \\
\text { sugars }\end{array}$ \\
\hline Meat accompaniments & 24 & 0 & 1 & 3 & 20 & 4 & $\begin{array}{l}\text { Mostly healthier options of discretionary foods } \\
\text { HSR failures suggest review sugar, added sugars }\end{array}$ \\
\hline
\end{tabular}




\begin{tabular}{|c|c|c|c|c|c|c|c|}
\hline $\begin{array}{l}\text { Major Food Categories (Extracts of } \\
\text { Relevant ADG text }{ }^{*} \text { ) }\end{array}$ & $\mathbf{n}$ & $\begin{array}{l}\text { Saturated Fat } \\
\text { Traffic Light Red }\end{array}$ & $\begin{array}{l}\text { Sodium Traffic } \\
\text { Light Red }\end{array}$ & $\begin{array}{l}\text { Total Sugar } \\
\text { Traffic Light Red }\end{array}$ & $\begin{array}{l}n \\
\text { ADG Failure }\end{array}$ & $\begin{array}{l}n \\
\text { HSR Failure }\end{array}$ & Policy Recommendation (Where $n \geq 10$ ) \\
\hline \multicolumn{8}{|l|}{ Spreads and dips } \\
\hline \multicolumn{8}{|l|}{ Dips } \\
\hline $\begin{array}{l}\text { Vegetable- based chilled dips } \\
\text { (hummus, tzatziki, guacamole) }\end{array}$ & 292 & 9 & 22 & 1 & 262 & 30 & $\begin{array}{l}\text { Mostly healthier options of discretionary foods } \\
\text { HSR failures suggest review salt, saturated fat }\end{array}$ \\
\hline Salsa & 68 & 0 & 16 & 0 & 52 & 16 & $\begin{array}{l}\text { Mostly healthier options of discretionary foods } \\
\text { HSR failures suggest review salt }\end{array}$ \\
\hline \multicolumn{8}{|l|}{ Savoury spreads } \\
\hline Relishes, pickles and chutneys & 124 & 0 & 19 & 57 & 48 & 76 & $\begin{array}{l}\text { Some healthier options of discretionary foods } \\
\text { HSR failures suggest review salt, sugar, added } \\
\text { sugars }\end{array}$ \\
\hline Other savoury spreads & 7 & 0 & 2 & 0 & 5 & 2 & \\
\hline Other spreads & 15 & 3 & 0 & 8 & 4 & 11 & HSR failures suggest review sugar, saturated fat \\
\hline Salad dressings and vinegars & 10 & 0 & 0 & 0 & 10 & 0 & None. Healthier options of discretionary foods \\
\hline
\end{tabular}

Snack foods

Guideline 2: Vegetables and fruit to limit ... Limit intake of fried vegetables such as potato and vegetable chips and crisps, which add extra kilojoules and salt. Chips and crisps are included in 'discretionary choices'

Guideline 3: Limit intake of foods containing saturated fats, added salt, added sugars and alcohol.

\begin{tabular}{|c|c|c|c|c|c|c|c|}
\hline Potato chips & 246 & 2 & 46 & 0 & 198 & 49 & $\begin{array}{l}\text { Many healthier options of discretionary foods } \\
\text { HSR failures suggest review salt, FVNL points }\end{array}$ \\
\hline Other snackfoods & 127 & 21 & 30 & 5 & 80 & 47 & $\begin{array}{l}\text { Many healthier options of discretionary foods } \\
\text { HSR failures suggest review salt, sat fat, FVNL } \\
\text { points }\end{array}$ \\
\hline Corn chips & 91 & 17 & 17 & 0 & 57 & 34 & $\begin{array}{l}\text { Many healthier options of discretionary foods } \\
\text { HSR failures suggest review salt, sat fat, FVNL } \\
\text { points }\end{array}$ \\
\hline Snack packs & 23 & 0 & 0 & 0 & 23 & 0 & Review ABS table definitions \\
\hline Vege-based snacks & 62 & 5 & 32 & 5 & 24 & 38 & $\begin{array}{l}\text { Some healthier options of discretionary foods } \\
\text { HSR failures suggest review salt, saturated fat, } \\
\text { sugar, FVNL points }\end{array}$ \\
\hline Popcorn & 55 & 2 & 2 & 1 & 50 & 5 & Mostly healthier options of discretionary foods \\
\hline
\end{tabular}




\begin{tabular}{|c|c|c|c|c|c|c|c|}
\hline $\begin{array}{l}\text { Major Food Categories (Extracts of } \\
\text { Relevant ADG text }{ }^{*} \text { ) }\end{array}$ & $\mathbf{n}$ & $\begin{array}{l}\text { Saturated Fat } \\
\text { Traffic Light Red }\end{array}$ & $\begin{array}{l}\text { Sodium Traffic } \\
\text { Light Red }\end{array}$ & $\begin{array}{l}\text { Total Sugar } \\
\text { Traffic Light Red }\end{array}$ & $\begin{array}{l}n \\
\text { ADG Failure }\end{array}$ & $\begin{array}{l}n \\
\text { HSR Failure }\end{array}$ & Policy Recommendation (Where $n \geq 10$ ) \\
\hline \multicolumn{8}{|l|}{ Special foods } \\
\hline \multicolumn{8}{|l|}{ Not specifically covered in ADG text. } \\
\hline Special foods & 2 & 0 & 0 & 0 & 2 & 0 & \\
\hline
\end{tabular}

Sugars, honey and related products

Guideline 3: Limit intake of foods high in saturated fats, added salt, added sugars and alcohol.

Limit foods high in added sugars including ... syrups...

\begin{tabular}{clllllll}
\hline Syrups & 14 & 0 & 0 & 5 & 5 & 9 & HSR failures suggest review sugar \\
\hline Sugars & 1 & 0 & 0 & 0 & 0 & 1 \\
\hline TOTAL & $\mathbf{4 1 0 5} \mathbf{2 3 5}$ & $\mathbf{5 1 0}$ & $\mathbf{2 9 6}$ & $\mathbf{3 1 3 0}$ & $\mathbf{9 7 5}$ \\
\hline
\end{tabular}

* For the purposes of this Appendix we have extracted direct statements from the Australian Dietary Guidelines Summary Document: https://www.nhmr.gov.au/_files_nhmrc/file/ your_health/healthy/nutrition/n55a_australian_dietary_guidelines_summary_131014_1.pdf. 


\section{References}

1. Lim, S.S.; Vos, T.; Flaxman, A.D.; Danaei, G.; Shibuya, K.; Adair-Rohani, H.; Amann, M.; Anderson, H.R.; Andrews, K.G.; Aryee, M.; et al. A comparative risk assessment of burden of disease and injury attributable to 67 risk factors and risk factor clusters in 21 regions, 1990-2010: A systematic analysis for the global burden of disease study 2010. Lancet (Lond. Engl.) 2012, 380, 2224-2260. [CrossRef]

2. Stuckler, D.; McKee, M.; Ebrahim, S.; Basu, S. Manufacturing epidemics: The role of global producers in increased consumption of unhealthy commodities including processed foods, alcohol, and tobacco. PLoS Med. 2012, 9, e1001235. [CrossRef] [PubMed]

3. PricewaterhouseCoopers. Weighing the Cost of Obesity: A Case for Action; PricewaterhouseCoopers: Sydney, Australia, 2015.

4. World Health Organization. 'Best Buys' and Other Recommended Interventions for the Prevention and Control of Noncommunicable Diseases, Updated (2017) Appendix 3 of the Global Action Plan for the Prevention and Control of Non-Communicable Diseases 2013-2020; World Health Organization: Geneva, Switzerland, 2017.

5. Sacks, G.; for the Food-EPI Australia Team. Policies for Tackling Obesity and Creating Healthier Food Environments: Scorecard and Priority Recommendations for Australian Governments; Deakin University: Melbourne, Australia, 2017.

6. National Health and Medical Research Council. Australian Dietary Guidelines; National Health and Medical Research Council (NHMRC): Canberra, Australia, 2013.

7. Senator the Hon Fiona Nash Assistant Minister for Health. Media Release: Health Star Rating System on Track; Senator the Hon Fiona Nash Assistant Minister for Health: Canberra, Australia, 2014.

8. Department of Health. The health Star Rating System (Website). Available online: http://healthstarrating. gov.au/internet/healthstarrating/publishing.nsf/content/home (accessed on 27 July 2017).

9. Australia and New Zealand Food Regulation Ministerial Council. Front of Pack Labelling Policy Statement. Available online: http://foodregulation.gov.au/internet/fr/publishing.nsf/Content/ 7F1E2F73C65A6463CA25801B0010D7FB/\$File/2009-10-Forum-Policy\%20Statement-Front\%20of\% 20Pack\%20Labelling.pdf (accessed on 18 April 2018).

10. Lawrence, M.; Dickie, S.; Woods, J. Do nutrient-based front-of-pack labelling schemes support or undermine food-based dietary guideline recommendations? Lessons from the Australian health star rating system. Nutrients 2018, 10, 32. [CrossRef] [PubMed]

11. Lawrence, M.; Pollard, C. A year on, Australia's health star food-rating system is showing cracks [online]. J. Home Econ. Inst. Aust. 2015, 22, 34-35.

12. Dunford, E.; Trevena, H.; Goodsell, C.; Ng, K.H.; Webster, J.; Millis, A.; Goldstein, S.; Hugueniot, O.; Neal, B. Foodswitch: A mobile phone app to enable consumers to make healthier food choices and crowdsourcing of national food composition data. JMIR mHealth uHealth 2014, 2, e37. [CrossRef] [PubMed]

13. Dunford, E.; Webster, J.; Metzler, A.B.; Czernichow, S.; Mhurchu, C.N.; Wolmarans, P.; Snowdon, W.; L'Abbe, M.; Li, N.; Maulik, P.K. International collaborative project to compare and monitor the nutritional composition of processed foods. Eur. J. Prev. Cardiol. 2012, 19, 1326-1332. [CrossRef] [PubMed]

14. Health Star Rating Advisory Committee (HSRAC). Health Star Rating System Style Guide V4, 4th ed.; Health Star Rating Advisory Committee (HSRAC): Canberra, Australia, 2016.

15. Australia New Zealand Food Standards Code-Standard 1.2.8-Nutrition Information Requirements. Available online: https:/ / www.legislation.gov.au/Details/F2011C00537 (accessed on 18 April 2018).

16. Health Star Rating Advisory Committee (HSRAC). Guide for Industry to the Health Star Rating Calculator (HSRC); version 5; Department of Health, Ed.; Health Star Rating Advisory Committee (HSRAC): Canberra, Australia, 2016.

17. Australian Bureau of Statistics. Australian Health Survey: Users' Guide, 2011-13-Discretionary Food List; Australian Bureau of Statistics: Canberra, Australia, 2014.

18. National Health and Medical Research Council. A Modelling System to Inform the Revision of the Australian Guide to Healthy Eating; National Health and Medical Research Council (NHMRC): Canberra, Australia, 2011.

19. United Kingdom Department of Health. Guide to Creating a Front of Pack (Fop) Nutrition Label for Pre-Packed Products Sold Through Retail Outlets; Department of Health, Ed.; United Kingdom Department of Health: London, UK, 2016. 
20. Emrich, T.E.; Qi, Y.; Lou, W.Y.; L'Abbe, M.R. Traffic-light labels could reduce population intakes of calories, total fat, saturated fat, and sodium. PLoS ONE 2017, 12, e0171188. [CrossRef] [PubMed]

21. Julia, C.; Ducrot, P.; Lassale, C.; Fézeu, L.; Méjean, C.; Péneau, S.; Touvier, M.; Hercberg, S.; Kesse-Guyot, E. Prospective associations between a dietary index based on the british food standard agency nutrient profiling system and 13-year weight gain in the su. Vi. Max cohort. Prev. Med. 2015, 81, 189-194. [CrossRef] [PubMed]

22. Tapsell, L.C.; Neale, E.P.; Satija, A.; Hu, F.B. Foods, nutrients, and dietary patterns: Interconnections and implications for dietary guidelines. Adv. Nutr. 2016, 7, 445-454. [CrossRef] [PubMed]

23. Dunford, E.; Cobcroft, M.; Thomas, M.; Wu, J. Technical Report: Alignment of the NSW Healthy Food Provision Policy with the Health Star Rating System; NSW Ministry of Health: Sydney, Australia, 2015.

24. Wellard, L.; Hughes, C.; Watson, W.L. Investigating nutrient profiling and health star ratings on core dairy products in australia. Public Health Nutr. 2016, 19, 2860-2865. [CrossRef] [PubMed]

25. Carrad, A.M.; Louie, J.C.Y.; Yeatman, H.R.; Dunford, E.K.; Neal, B.C.; Flood, V.M. A nutrient profiling assessment of packaged foods using two star-based front-of-pack labels. Public Health Nutr. 2016, 19, 2165-2174. [CrossRef] [PubMed]

26. Peters, S.A.; Dunford, E.; Jones, A.; Ni Mhurchu, C.; Crino, M.; Taylor, F.; Woodward, M.; Neal, B. Incorporating added sugar improves the performance of the health star rating front-of-pack labelling system in australia. Nutrients 2017, 9, 701. [CrossRef] [PubMed]

27. Codex Alimentarius Commission Committee on Food Labelling. Report of the Forty Fourth Session of the Codex Commitee on Food Labelling; Codex Alimentarius Commission Committee on Food Labelling: Ascunsion, Paraguay, 2017.

28. MP Consulting. Report on Submissions to the Five Year Review of the Health Star Rating System: Prepared for the commonwealth Department of Health; MP consulting: Melbourne, Australia, 2017.

29. Menday, H.; Neal, B.; Wu, J.H.Y.; Crino, M.; Baines, S.; Petersen, K.S. Use of added sugars instead of total sugars may improve the capacity of the health star rating system to discriminate between core and discretionary foods. J. Acad. Nutr. Diet. 2017, 117, 1921-1930.e1911. [CrossRef] [PubMed]

30. Louie, J.C.Y.; Moshtaghian, H.; Boylan, S.; Flood, V.M.; Rangan, A.; Barclay, A.; Brand-Miller, J.; Gill, T. A systematic methodology to estimate added sugar content of foods. Eur. J. Clin. Nutr. 2015, 69, 154. [CrossRef] [PubMed]

31. MP Consulting. Five Year Review of the Health Star Rating System-Navigation Paper; MP Consulting: Melbourne, Australia, 2018.

32. World Health Organization. Nutrient Profiling. Available online: http://www.who.int/nutrition/topics / profiling/en/ (accessed on 1 February 2017).

33. National Health and Medical Research Council. Eat for Health Educators Guide; National Health and Medical Research Council (NHMRC): Camberra, Australia, 2013.

(C) 2018 by the authors. Licensee MDPI, Basel, Switzerland. This article is an open access article distributed under the terms and conditions of the Creative Commons Attribution (CC BY) license (http://creativecommons.org/licenses/by/4.0/). 